\title{
Effects of Melatonin on Anterior Pituitary Plasticity: A Comparison Between Mammals and Teleosts
}

OPEN ACCESS

Edited by:

Vance L. Trudeau,

University of Ottawa, Canada

Reviewed by:

Hélène Volkoff,

Memorial University of Newfoundland

Canada

Hana Zemkova,

Academy of Sciences of the Czech Republic (ASCR), Czechia

${ }^{*}$ Correspondence:

Romain Fontaine

romain.fontaine@nmbu.no

Specialty section: This article was submitted to Neuroendocrine Science, a section of the journal

Frontiers in Endocrinology

Received: 11 September 2020

Accepted: 12 November 2020

Published: 11 January 2021

Citation:

Ciani E, Haug TM, Maugars G, Weltzien F-A, Falcón $J$ and Fontaine $R$ (2021) Effects of Melatonin on Anterior

Pituitary Plasticity: A Comparison Between Mammals and Teleosts.

Front. Endocrinol. 11:605111.

doi: 10.3389/fendo.2020.605111

\author{
Elia Ciani ${ }^{1}$, Trude M. Haug ${ }^{2}$, Gersende Maugars ${ }^{3}$, Finn-Arne Weltzien ${ }^{3}$, Jack Falcón ${ }^{4}$ \\ and Romain Fontaine ${ }^{3 *}$
}

\begin{abstract}
${ }^{1}$ Department of Pharmacy, Faculty of Mathematics and Natural Sciences, University of Oslo, Oslo, Norway, ${ }^{2}$ Department of Oral Biology, Faculty of Dentistry, University of Oslo, Oslo, Norway, ${ }^{3}$ Physiology Unit, Faculty of Veterinary Medicine, Norwegian University of Life Sciences, Oslo, Norway, ${ }^{4}$ Laboratoire Biologie des Organismes et Ecosystèmes Aquatiques (BOREA), MNHN, CNRS FRE 2030, SU, IRD 207, UCN, UA, Paris, France
\end{abstract}

Melatonin is a key hormone involved in the photoperiodic signaling pathway. In both teleosts and mammals, melatonin produced in the pineal gland at night is released into the blood and cerebrospinal fluid, providing rhythmic information to the whole organism. Melatonin acts via specific receptors, allowing the synchronization of daily and annual physiological rhythms to environmental conditions. The pituitary gland, which produces several hormones involved in a variety of physiological processes such as growth, metabolism, stress and reproduction, is an important target of melatonin. Melatonin modulates pituitary cellular activities, adjusting the synthesis and release of the different pituitary hormones to the functional demands, which changes during the day, seasons and life stages. It is, however, not always clear whether melatonin acts directly or indirectly on the pituitary. Indeed, melatonin also acts both upstream, on brain centers that control the pituitary hormone production and release, as well as downstream, on the tissues targeted by the pituitary hormones, which provide positive and negative feedback to the pituitary gland. In this review, we describe the known pathways through which melatonin modulates anterior pituitary hormonal production, distinguishing indirect effects mediated by brain centers from direct effects on the anterior pituitary. We also highlight similarities and differences between teleosts and mammals, drawing attention to knowledge gaps, and suggesting aims for future research.

Keywords: melatonin, adenohypophysis, photoperiod, melatonin receptors, seasonal reproduction, plasticity, endocrinology, light 


\section{INTRODUCTION}

Our environment is constantly changing. While some variations are fast and unpredictable (e.g. meteorological phenomena), others, such as solar cycles, moon phases, and seasons follow regular patterns. Photoperiod, the alternation of light and darkness, is the most reliable (noise-free, characterized by predictable rhythms over a long period of time) signal, allowing animals to synchronize their biological rhythms with both daily and seasonal changes. Photoperiod is conveyed by two types of signal: a neural message from photoreceptive structures to specific signaling centers in the brain, and a hormonal message $(1,2)$.

Melatonin is the key hormone that conveys rhythmic information from the environment, including photoperiod and temperature, to the organism. Circulating blood levels of melatonin exhibit a daily rhythm with higher levels during night than during day, and a seasonal rhythm with longer duration of the high level period during winter, as a consequence of the longer dark phase (Figure 1). Additionally, variations in temperature fine-tune those rhythms by modulating the amplitude of melatonin production. Duration and amplitude of melatonin release therefore provide clear information regarding time of the day and the year, and allow the synchronization of metabolic, physiological, and behavioral events, including growth, reproduction, and migration $(3,4)$.

Melatonin is synthesized from tryptophan in four enzymatic steps $(4,5)$. Tryptophan is first converted into 5 -hydroxytryptophan by the tryptophan hydroxylase, then converted into serotonin by the 5 hydroxy-tryptophan decarboxylase. Afterwards, serotonin is acetylated by the arylalkylamine $N$-acetyltransferase (AANAT), producing $N$-acetylserotonin, which is finally converted into melatonin by the hydroxyindole-O-methyl transferase. AANAT has been reported to be the limiting enzyme driving the rhythm of melatonin production (6). It has been hypothesized that the functional shift of AANAT from amine detoxification to melatonin synthesis played a critical role in the evolution of melatonin as a nighttime signal (7-9).

While the general mechanism of melatonin synthesis is conserved across vertebrates, the number of genes encoding

\footnotetext{
Abbreviations: $1 \mathrm{R}$ to $4 \mathrm{R}$, 1 st to 4 th whole genome duplication; AANAT, Arylalkylamine N-acetyltransferase; AC, Adenylyl cyclase; ACTH, Adrenocorticotropic hormone; ARC, Arcuate nucleus; ATP, Adenosine 5'-triphosphate; cAMP, Cyclic adenosine 5'-monophosphate; cGMP, Cyclic guanosine monophosphate; CREB, Calcium/cAMP response element binding protein; Cryl, Cryptochrome1; DIO2/3, Deiodinase 2/3; ER, Endoplasmatic reticulum; EYA, Eyes absent homologue; FSH/ FSHB, Follicle-stimulating hormone/FSH beta subunit; GH, Growth hormone; GnIH, Gonadotropin inhibiting hormone; GnRH, Gonadotropin releasing hormone; GnRHR, Gonadotropin releasing hormone receptor; LP/SP, Long photoperiod/Short photoperiod; LH/LHB, Luteinizing hormone/LH beta subunit; LL/DD, Constant light/Constant darkness; ME, Median eminence; MSH, Melanocyte-stimulating hormone; MTNR, Melatonin receptors; PD, Pars distalis; Per1, Period1; PI, Pars intermedia; PKA, Protein kinase A; PKC, Protein kinase C; PLC, Phospholipase C; POA, Preoptic area; POMC, Pro-opiomelanocortin; PRL, Prolactin; PT, Pars tuberalis; RFRP, RFamide related peptide; SCN, Suprachiasmatic nucleus; SL, Somatolactin; T3, Triiodothyroxine; T4, Thyroxine; TEF, Thyrotroph embryonic factor; TH, Thyroid hormone; TRH, Thyrotropin-releasing hormone; TSH/TSHB, Thyroid stimulating hormone/TSH beta subunit.

Gene and protein nomenclature: The present review follows the ZFIN nomenclature conventions for protein and gene names in mammals and fish (e.g. Mammalian protein: LHB; Mammalian gene: Lhb; fish protein: Lhb; fish gene: lhb).
}

the different enzymes differs between mammals and fish, as a consequence of whole genome duplications that occurred in the vertebrate lineage. Indeed, after the two successive whole genome duplications (referred to as $1 \mathrm{R}$ and $2 \mathrm{R}$ ) which occurred at the base of the vertebrate lineage (10-12), a third one (3R) occurred at the base of the teleost fish lineage (13), and a fourth one (4R) occurred independently in both the cyprinid and salmonid lineages $(14,15)$. Following a genome duplication, one of the paralogous genes may be lost or duplicated paralogues may acquire differential specialized functions over time, and an increase in the number of paralogues, expands the hormonereceptor combinations (16). In contrast to mammals, all actinopterygians, including the teleosts, possess at least two aanat genes (aanat1 and aanat2) (9, 17), resulting probably from the whole genomic duplications that occurred in the vertebrate lineage (18). Additionally, aanat1 and aanat 2 have also been duplicated during the 3R (18). While one of the aanat2 paralogues was lost early after the $3 \mathrm{R}$, this was not the case for the aanat 1 paralogues and, to date, some fish possess two Aanat1 isoforms (aanat1a and aanat1b) or either one of them. While aanat1 genes are mostly expressed in the retina, brain, and peripheral tissues, aanat 2 expression is specific to the pineal gland $(19,20)$, the site of production of circulating melatonin in both mammals (21) and teleosts $(22,23)$. Melatonin is then released from the pineal gland into the blood and cerebrospinal fluid to be transported to its target organs.

Melatonin acts through several different receptors (MTNR), belonging to the G-protein coupled receptor superfamily (24). Four sub-groups of Mtnr, arising from the $1 \mathrm{R}$ and $2 \mathrm{R}$, have been characterized in vertebrates: MTNR1A (Mel1a or MT1), MTNR1B (Mel1b or MT2), MTNR1C (Mel1c or GPR50), and MTNR1D (Mtnr1A-like or Mel1d) (25-28). In mammals, melatonin action is mediated only through two MTNR paralogues, MTNR1A and MTNR1B, since the Mtnrld gene was lost in the mammalian lineage and MTNR1C lost its ability to bind melatonin (28). Teleosts may possess up to $7 \mathrm{Mtnr}$ paralogues (excluding the polyploid cyprinids), arising from the $3 \mathrm{R}$ and $4 \mathrm{R}(25,28)$. MTNR affects different intracellular signaling pathways, including cAMP/ PKA, via $\mathrm{G}_{\mathrm{i}}$ proteins (MTNR1A and MTNR1B) $(29,30), \mathrm{PLC} / \mathrm{PKC}$ via $\mathrm{G}_{\mathrm{q}}$-proteins (MTNR1A and MTNR1C) (31) and cGMP via $\mathrm{G}_{\mathrm{i} / \mathrm{o}}$ proteins (MTNR1B) $(32,33)$. In medaka (Oryzias latipes), all four Mtnr subtypes are functional and decrease cAMP in response to melatonin exposure (27). Interestingly, melatonin receptors in Atlantic salmon (Salmo salar) increase cAMP when activated by melatonin (25). The broad distribution of MTNR expression in the central nervous system (including the pituitary) and peripheral tissues suggests melatonin can have widespread effects $(28,34)$.

The pituitary is a key endocrine gland in all vertebrates, involved in the regulation of many important physiological processes (35). These include growth, puberty, seasonal sexual maturation, metabolism, and homeostasis, which exhibit cycling components over the day, the year and the life cycle. Located below the hypothalamus, the pituitary is composed of two main parts with different developmental origins (36): the anterior pituitary (adenohypophysis) and the posterior pituitary (neurohypophysis) (Figure 2). The neurohypophysis originates from a down-growth of the diencephalon and is mainly composed of nerve terminals from 


\section{SPRING}

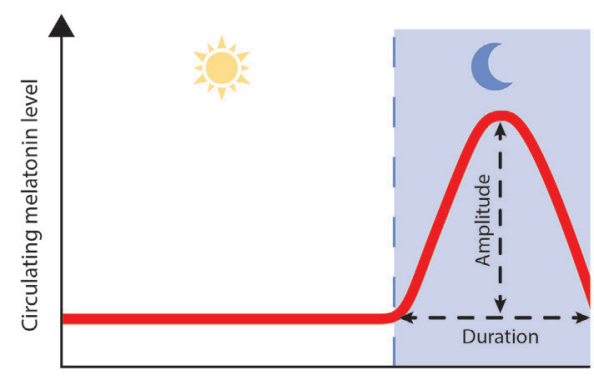

WINTER

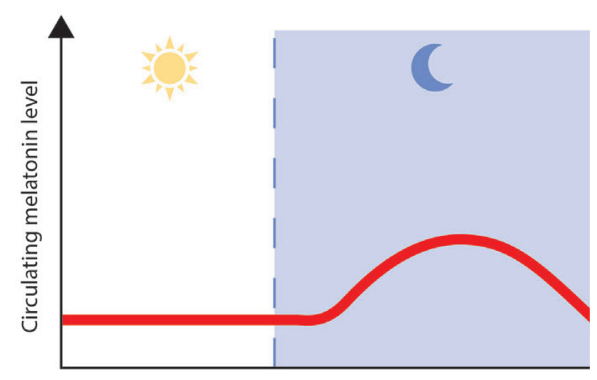

FIGURE 1 | Schematic representation of daily and seasonal fluctuation in plasma melatonin levels.

neuroendocrine cells in the preoptic area (POA) and the hypothalamus of the brain, which are considered today as two distinct regions (37). The adenohypophysis originates from an upgrowth of the pharyngeal ectoderm and endoderm (38) and can be histologically divided in the pars intermedia (PI), the pars distalis (PD), and the pars tuberalis (PT), the latter present in mammals but not in teleosts. The adenohypophysis hosts several hormone-producing cell types: gonadotropes (producing the gonadotropins: follicle-stimulating and luteinizing hormones, FSH and LH), lactotropes (prolactin, PRL), somatotropes (growth hormone, GH), thyrotropes (thyrotropin, TSH), corticotropes (adrenocorticotropin, ACTH), and melanotropes (melanocytestimulating hormone, MSH) (39). Teleosts also possess one additional cell type, the somatolactotropes responsible for the production of somatolactin (Sl) (40).

The activity of pituitary endocrine cells is constantly changing over time, adjusting the hormonal production to changing physiological needs. It is controlled by factors produced from signaling centers in the brain, mainly the POA and hypothalamus, and from peripheral organs, which provide positive and negative feedback to these centers and to the pituitary $(41,42)$. In mammals, $\mathrm{POA} /$ hypothalamic neurons project to the median eminence (ME) of the hypothalamus, releasing their hormones into the hypophysial portal system where they are transported via the blood stream to the pituitary endocrine cells (42). Teleosts, on the other hand, lack the hypophysial portal system, and instead the POA/hypothalamic neurons innervate the pituitary, releasing their neurohormones directly at target cells or into pituitary blood vessels (41, 43). Pituitary hormonal production is regulated through both modulation of the activity of individual cells, and regional reorganizations of the anterior pituitary in terms of structure or cell composition, as discussed previously for gonadotropes $(38,44)$.

While pituitary plasticity is influenced by environmental factors, the role that melatonin plays in translating fluctuations of environmental conditions into pituitary hormonal production
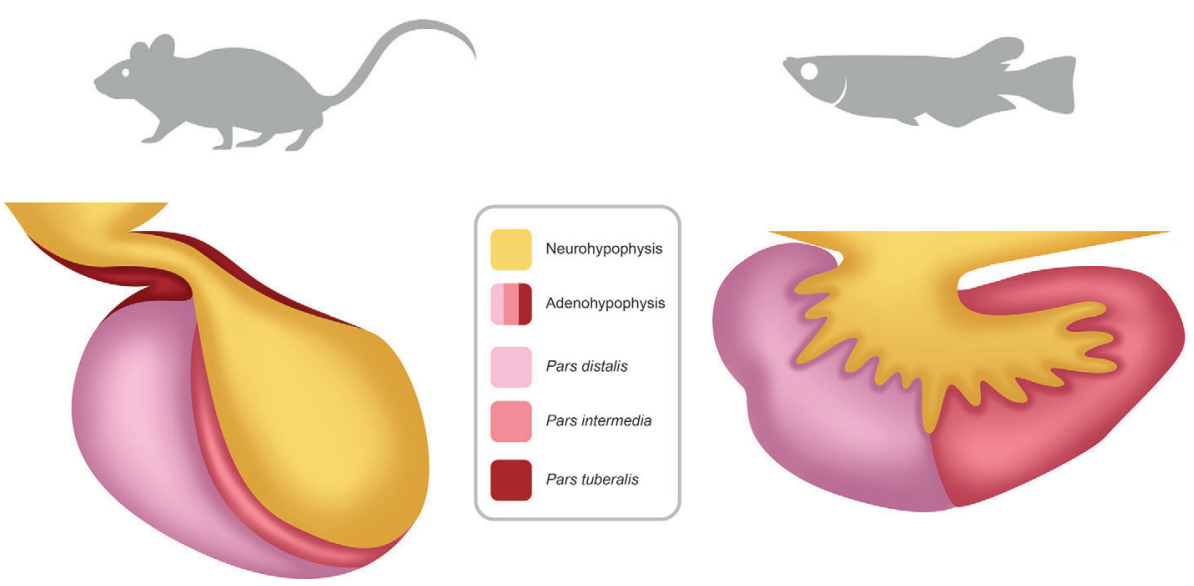

FIGURE 2 | Schema of the pituitary in mammals and teleosts. The pituitary is composed of two main parts: the neurohypophysis (posterior pituitary) and the adenohypophysis (anterior pituitary). The neurohypophysis is mainly composed of neuron terminals from neuroendocrine cells with cell soma located in the preoptichypothalamic region of the brain. The adenohypophysis contains different hormones producing cell types and can be anatomically divided in pars distalis, pars intermedia and, in mammals but not in teleosts, pars tuberalis. 
is not always clear. In addition, the mechanisms of melatonin action are complex, as both direct effects on pituitary endocrine cells and indirect effects through neuro/hormonal signaling centers combine to regulate pituitary activity. In this review, we describe the known pathways through which melatonin modulates anterior pituitary hormonal production, distinguishing between indirect effects mediated by brain centers and direct effects on the anterior pituitary. We also highlight similar and divergent features between teleosts and mammals, and emphasize important unsolved questions for future research.

\section{BRAIN-MEDIATED EFFECTS OF MELATONIN ON ANTERIOR PITUITARY ENDOCRINE CELLS}

\section{Mammals}

Endocrine pituitary cells are primarily controlled by brain signaling centers, mainly the preoptic and hypothalamic area (42) (Figure 3, Table 1), which integrate nervous and hormonal signals of different origins. These brain regions are characterized by the presence of numerous melatonin binding sites as shown in rodents and ruminants (60-66). Although the suprachiasmatic nucleus $(\mathrm{SCN})$ of the hypothalamus drives the rhythmic production of melatonin in mammals (67), the present review will focus on known effects of melatonin on brain centers directly regulating pituitary endocrine production, as discussed below.

\section{Gonadotropes}

Gonadotropes are the most investigated pituitary cell type in relation to melatonin, due to the high scientific and economic interest around the seasonal control of reproduction. Indeed, gonadotropes produce the two gonadotropins (FSH and $\mathrm{LH}$ ), key hormones in the control of reproduction, which are heterodimeric glycoproteins composed of a common $\alpha$-subunit (GPH $\alpha$, also shared with TSH) and a hormone-specific $\beta$ subunit (LH $\beta$ or FSH $\beta$ ) conferring the specific biological activity (42).

\section{GnRH}

Mammalian gonadotropin-releasing hormone (GnRH1 or mGnRH-I), a 10-amino acid neuropeptide produced from POA/ hypothalamic neurons, is the main regulator of gonadotropin synthesis and secretion (42). Most mammals also possess a second form (GnRH2 or cGnRH-II), expressed in the midbrain and other organs, which is primarily involved in other functions than regulating gonadotropin release. Vertebrates also possess two major types of GnRH receptors (type I with the GnRHR1a and II with the GnRHR2c) (68), however in many mammalian species, GnRHR2c receptor is not functional (69).

Melatonin influences $\mathrm{GnRH}$ production and thus the reproductive axis in seasonal breeders. Melatonin administration and short photoperiod (SP) cause testicular regression in the male summer breeder jerboa (Jaculus orientalis), a desert hibernating rodent, by inhibiting $\mathrm{GnRH}$ release (47). In contrast, melatonin administration in the ewe (Ovis aries, a winter breeder) increases the pulsatile GnRH secretion from hypothalamus, and pituitary $\mathrm{LH}$

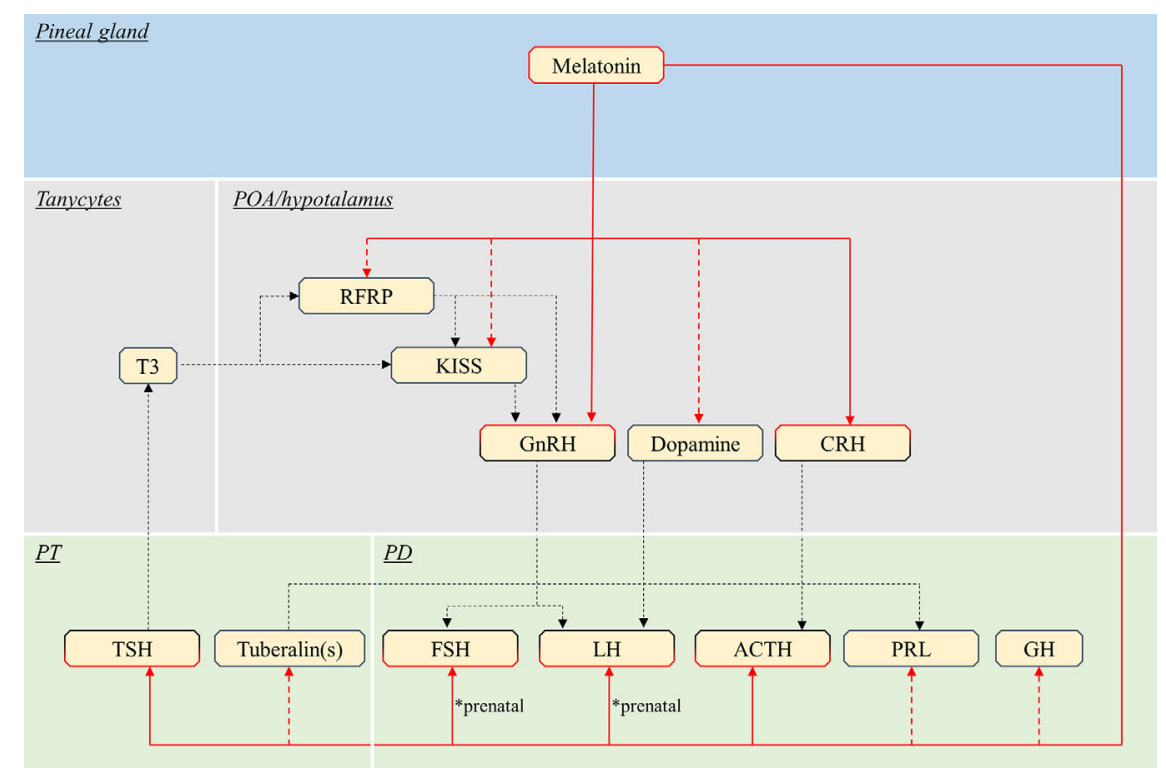

FIGURE 3 | Schematic view of the putative pathways through which melatonin influence pituitary endocrine activity in mammals. Red continuous lines indicate cell types directly targeted from melatonin. Dashed red lines indicate cells influenced by melatonin via yet unidentified interneurons, paracrine signals or MTNR. Note that melatonin might act only on a few of the illustrated pathway, in different species (see text). Black dashed lines indicate all other interactions between brain and pituitary. POA, preoptic area; PT, pars tuberalis; PD, pars distalis; T3, triiodothyronine; RFRP, RFamide-related peptide; KISS, kisspeptin; GnRH, gonadotropinreleasing hormone; $\mathrm{CRH}$, corticotropin-releasing hormone; $\mathrm{TSH}$, thyroid-stimulating hormone; FSH, follicle-stimulating hormone; $\mathrm{LH}$, luteinising hormone; $\mathrm{ACTH}$, adrenocorticotropic hormone; PRL, prolactin; GH, growth hormone. 
TABLE 1 | Summary of the known effects of melatonin POA/hypothalamic neurons controlling pituitary hormonal production in mammals.

\begin{tabular}{|c|c|c|c|c|c|}
\hline Target & $\begin{array}{l}\text { Effect of } \\
\text { melatonin }\end{array}$ & Species & $\begin{array}{l}\text { Breeding } \\
\text { season/ } \\
\text { Photoperiod }\end{array}$ & Description & Reference \\
\hline \multicolumn{6}{|l|}{ Mammals } \\
\hline \multirow[t]{4}{*}{$\mathrm{GnRH}$} & Stimulates & Sheep & Winter/SP & Melatonin administration increases $\mathrm{GnRH}$ secretion & $\begin{array}{l}\text { Bittman et al. (45) } \\
\text { Viguié et al. (46) }\end{array}$ \\
\hline & Inhibits & Jerboa & Summer/LP & Short photoperiod and melatonin administration downregulate $\mathrm{GnRH}$ release & El Qandil et al. (47) \\
\hline & Inhibits & $\begin{array}{l}\text { GT1-7 mouse GnRH } \\
\text { cell line }\end{array}$ & & Melatonin reduces GnRH mRNA and protein levels in GT1-7 cell line & Roy et al. (48) \\
\hline & Modulates & Rat & $\begin{array}{l}\text { non-seasonal } \\
\text { breeder }\end{array}$ & $\begin{array}{l}\text { Melatonin augments/reduces GABA-induced currents in GnRH neurons in a } \\
\text { sex dependent way }\end{array}$ & Sato et al. (49) \\
\hline \multirow[t]{4}{*}{ KISS } & Inhibits & Syrian hamster & Summer/LP & Melatonin reduces KISS1 mRNA & $\begin{array}{l}\text { Revel et al. (50) } \\
\text { Ansel et al. (51) }\end{array}$ \\
\hline & & Turkish hamster & Summer/LP & Melatonin reduces KISS1 mRNA & Piekarski et al. (52) \\
\hline & & Striped hamster & Summer/LP & Melatonin reduces KISS1 mRNA & Li et al. (53) \\
\hline & & Rat & $\begin{array}{l}\text { non-seasonal } \\
\text { breeder }\end{array}$ & Melatonin reduces KISS1 mRNA & Oliveira et al. (54) \\
\hline \multirow[t]{2}{*}{ RFRP } & Inhibits & Syrian hamster & Summer/LP & Melatonin (and SP) reduces RFRP-3 mRNA and protein & $\begin{array}{l}\text { Mason et al. (55) } \\
\text { Revel et al. (56) }\end{array}$ \\
\hline & & Siberian hamster & Summer/LP & Melatonin (and SP) reduces RFRP-3 mRNA and protein & $\begin{array}{l}\text { Ubuka et al. (57) } \\
\text { Revel et al. (56) }\end{array}$ \\
\hline \multirow[t]{2}{*}{ Dopamine } & Stimulates & Syrian hamster & Summer/LP & Melatonin administration stimulates tyrosine hydroxylase activity in males & Alexiuk et al. (58) \\
\hline & Inhibits & Sheep & Winter/SP & Melatonin implants inhibit tyrosine hydroxylase activity & Viguié et al. (59) \\
\hline
\end{tabular}

secretion $(45,46)$. While suggesting a connection between melatonin level and $\mathrm{GnRH}$ production, these in vivo experiments do not reveal whether melatonin acts directly on GnRH neurons, indirectly via interneurons or through a combination of both. However, in vitro experiments using the GT1-7 mouse hypothalamic GnRH cell line reveal that GnRH neurons express MTNR1A (MT1) and MTNR1B (MT2) (48) and demonstrate that melatonin inhibits both GnRH mRNA expression and protein secretion $(48,70)$.

Melatonin action might be modulated in a sexually dimorphic way in rodents as higher mRNA levels of Mtnrla (MT1) are detected in male than female rat (Rattus norvegicus) $\mathrm{GnRH}$ neurons, while Mtnr1b (MT2) is not expressed in either sex (71). Sexual dimorphism of the melatonin response in $\mathrm{GnRH}$ neurons is supported by another in vitro study, where melatonin augmented the membrane current induced by gamma-aminobutyric acid $\left(\mathrm{GABA}_{\mathrm{A}}\right)$ in $70 \%$ and attenuated it in $18 \%$ of neurons from adult males, while it augmented the current in only $25 \%$ and attenuated it in $61 \%$ of the neurons from adult females (49). Nevertheless, the physiological relevance of the direct actions of melatonin on $\mathrm{GnRH}$ neuron activity in vivo remains controversial, as melatonin might additionally act on upstream signals, such as KISS1, RFRP3 and T3, as discussed below.

\section{RFRP3 (GnIH)}

RFamide related peptide3 (RFRP3) is the mammalian orthologue of avian $\mathrm{GnIH}$, which was originally identified in birds as an inhibitory factor of gonadotropin synthesis and release, by acting on both GnRH neurons and gonadotropes. RFRP3 neurons are located in the paraventricular nucleus of the hypothalamus (42). Interestingly, the effects of RFRP3 on gonadotropin synthesis are deeply influenced by sex and timing of administration in mammals. For instance, in Syrian hamsters (Mesocricetus auratus), RFRP3 inhibits gonadotropin secretion in ovariectomized females (72) while it stimulates $\mathrm{GnRH}$ and gonadotropin secretion in males (73). In male Siberian hamster (Phodopus sungorus), RFRP3 directly injected into the third ventricle inhibits LH release when applied under LP, but has excitatory effects under SP (57), suggesting that melatonin might differentially influence the activity of RFRP3 neurons over the seasons.

In summer breeders, such as Siberian and Syrian hamster, both SP and melatonin injection reduces RFRP3 protein and mRNA levels, as well as decrease RFRP3 fibre density and number of projections to $\mathrm{GnRH}$ neurons (55-57). These studies also show that pinealectomy abolishes the effects of photoperiod manipulation, while subsequent melatonin exposure re-establishes them. While sex steroids are known to induce positive or negative feedback on hypothalamic signaling centers, the SP-induced reduction in RFRP3 protein and mRNA levels observed in male hamsters is not a consequence of reduced circulating steroid levels, since neither castration nor testosterone implants alter RFRP3 synthesis. These data therefore strongly suggest that melatonin is responsible for the inhibition of RFRP3.

In winter breeders, such as sheep, SP decreases both RFRP3 mRNA and protein levels, and RFRP3 neuron projections to GnRH neurons $(74,75)$. Similarly, in brushtail possum (Trichosurus vulpecula) females, the number of RFRP3 neurons decreases during winter (76). Interestingly, in the laboratory Wistar rat, a non-photoperiodic breeder, no effect of photoperiod manipulation was detected on RFRP3 neurons (56). These results suggest that the photoperiodic control of melatonin on RFRP3 is conserved among mammals, with inhibiting effects in both summer and winter breeders, while the downstream effects of the RFRP3 system on gonadotropin secretion might diverge to adapt to long-day or shortday breeding strategies.

Whether melatonin acts directly on RFRP cells in mammals requires further investigations as there is still a lack of evidence for 
colocalization with MTNR, or studies clearly demonstrating a direct action of melatonin on RFRP3 neurons, as previously discussed by Kriegsfeld and collaborators (77).

\section{Kisspeptin}

KISS neurons produce the neuropeptide kisspeptin (KISS) and stimulate $\mathrm{GnRH}$ synthesis and secretion, thereby regulating gonadotrope cell activity (78). Located in two discrete hypothalamic nuclei, the arcuate nucleus (ARC) in all mammals and the anteroventral periventricular area around the $3^{\text {rd }}$ ventricle in rodents or the POA in non-rodent mammals, the activity and number of KISS neurons display a marked photoperiodic/seasonal pattern, as shown below.

In the winter breeding sheep, SP upregulates both ARC KISS1 mRNA and protein, and increases the number of both ARC KISS neurons and synaptic connections from KISS to GnRH neurons (75). In contrast, melatonin inhibits the activity of KISS neurons in summer breeders. For instance, using a combination of photoperiod manipulation, pinealectomy and melatonin administration Revel and colleagues (50) and Ansel and colleagues (51) demonstrated that melatonin clearly reduces ARC KISS1 mRNA in Syrian hamsters, an effect further modulated by the negative steroid feedback. Similar inhibitory effects of melatonin on KISS1 mRNA were detected in Turkish (Mesocricetus brandti) (52) and striped (Cricetulus barabensis) (53) hamsters but also in the rat, a non-seasonal breeder (54). Interestingly, in the Siberian hamster, ARC KISS1 mRNA levels are lower under LP due to a robust negative sex steroid feedback overriding the melatonin signal, since castration in LP animals restores high KISS1 mRNA levels (79). Therefore, the role of melatonin among different species, or different reproductive stages, might be difficult to identify considering the impact of steroid feedbacks on ARC KISS neurons.

Although a direct effect of melatonin on KISS1 mRNA levels was detected in a hypothalamic cell line from rat (80), Mtnr expression has not been found in sheep KISS neurons, neither during the breeding nor during the non-breeding season (81). These results suggest that the effects of melatonin on KISS neurons could be mediated upstream.

\section{Dopamine}

The activity of the dopaminergic neurons located within the POA/hypothalamic area, which are involved in the inhibition of gonadotropin synthesis and release (82), also appears to be regulated by melatonin. For instance, in the ewe, a winter breeder, melatonin implants inhibit the activity of tyrosine hydroxylase (the rate-limiting enzyme in the dopamine synthesis pathway) in the median eminence, while stimulating LH release (59). In contrast, in male Syrian hamsters, in which SP elicits testicular regression, melatonin administration stimulates tyrosine hydroxylase activity in the median eminence, increasing dopamine synthesis and release (58).

\section{Other Endocrine Cells in the Pars Distalis}

Melatonin plays a role in the regulation of other pituitary endocrine cell types in mammals by regulating their main hypophysiotropic factors.

Corticotrope cells produce ACTH, a hormone involved in various physiological processes including the stress response (promoting the release of cortisol from the adrenal gland) and the control of numerous daily and seasonal physiological rhythms (including sleep) (83). Corticotropes are mainly regulated by corticotropin releasing hormone $(\mathrm{CRH})$ neurons located in the paraventricular nucleus. Melatonin exerts a stressprotective effect in mammals $(84,85)$. Daily melatonin administration reduces the ACTH secretory response to acute and chronic stress in rat $(86,87)$. In humans (Homo sapiens), oral melatonin administration in blind individuals normalizes the temporal pattern of ACTH and cortisol plasma concentrations during sleep, suppressing the pituitary-adrenal activity during early sleep and activating it during late sleep (88). Melatonin might modulate ACTH production by acting directly on hypothalamic CRH neurons, which express the MTNR1A in humans (89).

Lactotrope cells produce PRL, a peptide hormone involved in reproduction (lactation), moulting, metabolism, and immune responses. PRL secretion is stimulated by releasing factors from the PT and inhibited by dopamine secreted by tuberoinfindibular dopaminergic neurons located in the dorsomedial arcuate nucleus (90-92). Exogenous melatonin administration and SP decrease the PRL secretion in ruminants. For instance, oral melatonin administration inhibits PRL secretion in lactating ewes (93). SP reduces PRL secretion in cows [Bos taurus (94)], while melatonin oral administration reduces PRL release in both prepubertal (95) and mature (96) cows. The pathway involved in the melatonin-mediated PRL inhibition seems to be mediated through a dopamine-independent mechanism, since melatonin administration inhibits PRL release even in rams where the hypothalamo-pituitary connection has been surgically disrupted $(97,98)$ and melatonin implants reduce PRL secretion without altering dopamine content in ewe (59).

Despite the involvement of both somatotropes and thyrotropes in seasonal physiological activity, there is no clearly established role for melatonin signaling to their POA/hypothalamic regulators. Somatotrope cells produce $\mathrm{GH}$, a peptide hormone involved in numerous physiological processes including growth, metabolism and cellular proliferation. The main hypothalamic regulators of somatotropes are growth hormone releasing hormone (GHRH) and somatostatin, which stimulates and inhibits $\mathrm{GH}$ production, respectively (99). Thyrotrope cells produce $\mathrm{TSH}$, a heterodimeric glycoprotein hormone, composed of an $\alpha-(\mathrm{GPH} \alpha)$ and a $\beta$ (TSH $\beta)$ subunit, involved in different seasonal physiological functions including reproduction and growth (100). Two distinct populations of thyrotropes, with distinct morphology and secretory activity are located in the PT and PD (101-103). Thyrotropinreleasing hormone (TRH) produced by hypothalamic neurons is the main regulator of PD TSH synthesis (104). By contrast, TRH has no effect on PT thyrotrope activity (105), which is controlled by other signals including melatonin, as discussed in section 3 below on direct effects of melatonin.

\section{Teleosts}

In teleosts, endocrine pituitary cells are also mainly controlled by brain signaling centers in the preoptic and hypothalamic areas (41), which are characterized by the presence of numerous melatonin binding sites (106-108). The effects of melatonin on 
these brain centers, and thus indirectly on pituitary activity, have been studied mainly in the context of reproduction in teleosts, such as in the salmon (109) and eel (110) where melatonin has been shown to play an important role in puberty. Therefore, the available knowledge and thus the discussion in the present review, only concern gonadotropes (Figure 4, Table 2).

\section{Gonadotropes}

In contrast to mammals, the teleost gonadotropes mainly produce Lh and Fsh in distinct cells, with only a small portion of gonadotropes producing both hormones in some species (43). However, like in mammals, pituitary gonadotropin synthesis and release are regulated by POA/hypothalamic signaling centers, including Gnrh, Gnih, Kiss, and dopamine neurons (41, 123, 124).

\section{Gnrh}

Fish possess up to three genes encoding Gnrh (gnrh1, gnrh2, gnrh3) $(16,41)$. In some teleost species, melatonin stimulates gonadotropin production by upregulating Gnrh expression. For instance, in adult female zebrafish (Danio rerio), melatonin exposure via immersion increases the mRNA levels of brain gnrh 3 and pituitary $l h b$ (111). In a second study on adult zebrafish females, brain gnrh 3 mRNA levels were increased in both constant light (LL) and constant darkness (DD) as compared to normal light-dark cycles (117). The inconsistent responses of gnrh highlight the importance of the experimental conditions, and suggest the presence of different regulatory mechanisms activated by melatonin exposure and photoperiod manipulation, as mentioned in the introduction.

In other teleost species, melatonin inhibits gonadotropin production by downregulating Gnrh expression. In Nile tilapia (Oreochromis niloticus), whose development and reproduction are suppressed under SP $(125,126)$, intraperitoneal melatonin injections simultaneously reduce gnrh 1 mRNA in the brain and both $l h b$ and $f s h b$ mRNA in the pituitary (112). Several studies were performed in male sea bass (Dicentrarchus labrax). Both intraperitoneal melatonin injections (114) and melatonin implants (115) downregulate brain mRNA levels of the two hypophysiotropic forms of Gnrh, gnrh1 and gnrh3. Remarkably, these genes show natural daily variations in mRNA levels, with lower levels during the mid-dark phase, when plasma melatonin is highest (114). Melatonin implants also decrease pituitary mRNA levels of Gnrh receptors (named gnrhr2bal and gnrhrlcb, according to recent phylogeny, (68) but named gnrhr-II-1a and gnrhr-II-2b, respectively, in the study), as well as $f s h b$ (115). Interestingly, pituitary Gnrh1 protein content shows daily variation with minimum levels during night time, under both natural photoperiod and LP (127). While downregulating the Gnrh system, melatonin implants also reduce plasma gonadotropins (Lh and Fsh) and androgens (testosterone, T and 11-keto-testosterone,

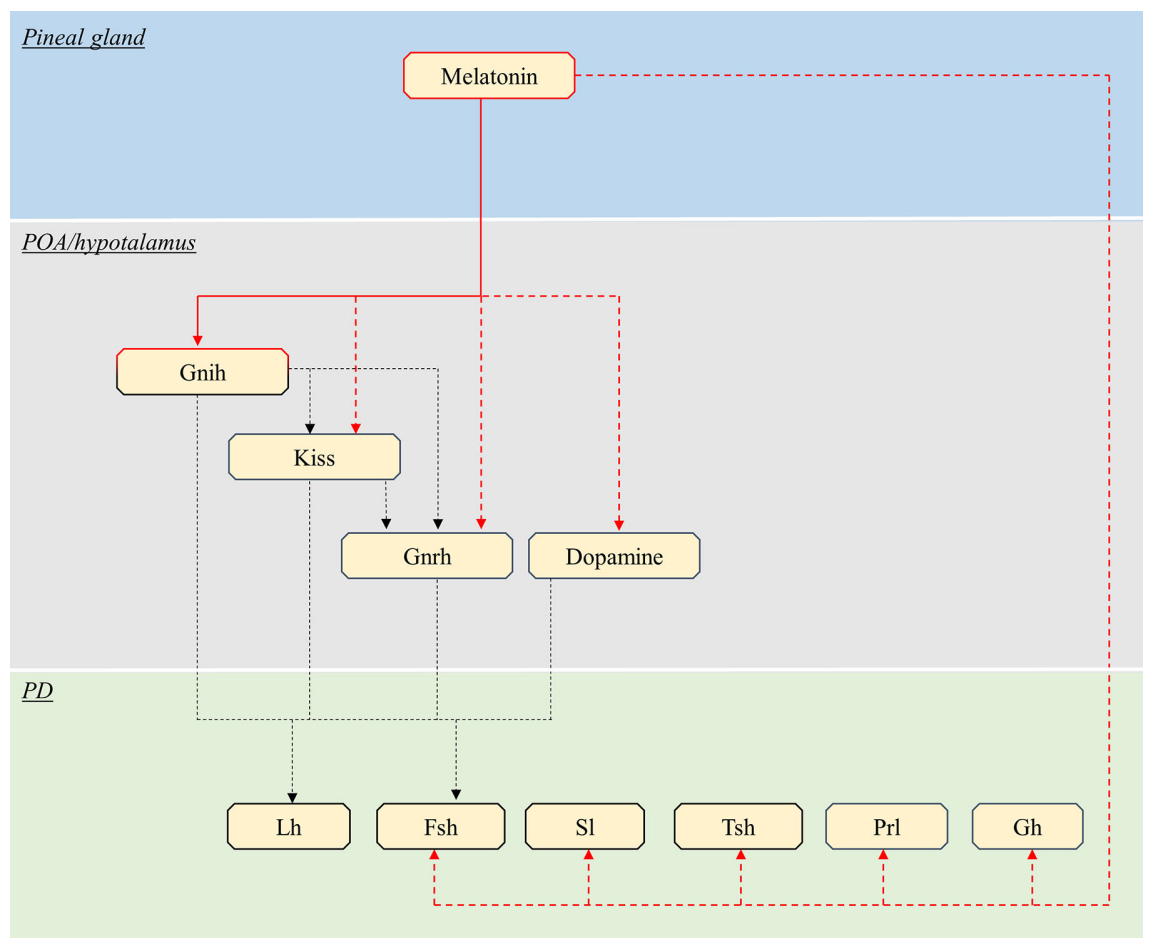

FIGURE 4 | Schematic view of the putative pathways through which melatonin influence pituitary endocrine activity in teleosts. Red continuous lines indicate cell types directly targeted from melatonin. Dashed red lines indicate cells influenced by melatonin via yet unidentified interneurons, paracrine signals or Mtnr Note that melatonin might act only on a few of the illustrated pathway, in different species (see text). Black dashed lines indicate all other interactions between brain and pituitary. POA, preoptic area; PD, pars distalis; Kiss, kisspeptin; Gnrh, gonadotropin-releasing hormone; Lh, luteinising hormone; Fsh, follicle-stimulating hormone; Sl, somatolactin; Tsh, thyroid-stimulating hormone; PRL, prolactin; GH, growth hormone. 
TABLE 2 | Summary of the known effects of melatonin POA/hypothalamic neurons controlling pituitary hormonal production in teleosts.

\begin{tabular}{|c|c|c|c|c|c|}
\hline Target & $\begin{array}{l}\text { Effect of } \\
\text { melatonin }\end{array}$ & Species & $\begin{array}{l}\text { Spawning } \\
\text { season/ } \\
\text { Photoperiod }\end{array}$ & Description & Reference \\
\hline \multicolumn{6}{|l|}{ Teleosts } \\
\hline \multirow[t]{6}{*}{ Gnrh } & Stimulates & Zebrafish & $\begin{array}{l}\text { Spring/LP } \\
\text { (Daily in } \\
\text { captivity) }\end{array}$ & $\begin{array}{l}\text { Melatonin exposure via water upregulates brain gnrh3 expression (adult } \\
\text { females) }\end{array}$ & Carnevali et al. (111) \\
\hline & Inhibits & Nile tilapia & Spring/LP & Melatonin injections downregulate brain gnrh1 expression & Kim et al. (112) \\
\hline & & Masu salmon & Autumn/SP & Oral melatonin administration ( $50 \mu \mathrm{g} / \mathrm{g}$ feed) decreases Gnrh release & Amano et al. (113) \\
\hline & & Sea bass & Spring/LP & Melatonin injections downregulate brain gnrh1 and gnrh3 expression & Servili et al. (114) \\
\hline & & & & Melatonin implants downregulate brain gnrh1 and gnrh3 and gnrhr-II-1a -2b & Alvarado et al. (115) \\
\hline & None & European eel & Spring/LP & Melatonin implants have no effects on gnrh expression & Sébert et al. (116) \\
\hline \multirow[t]{2}{*}{ Gnih } & Stimulates & Nile tilapia & Spring/LP & Melatonin injections upregulate brain gnih expression & Kim et al. (112) \\
\hline & Inhibits & Zebrafish & $\begin{array}{l}\text { Spring/LP } \\
\text { (Daily in } \\
\text { captivity) }\end{array}$ & Melatonin downregulates gnih expression in cultured hypothalamus & Yumnamcha et al. (117) \\
\hline \multirow[t]{2}{*}{ Kiss } & Stimulates & Zebrafish & $\begin{array}{l}\text { Spring/LP } \\
\text { (Daily in } \\
\text { captivity) }\end{array}$ & $\begin{array}{l}\text { Melatonin exposure via water upregulates brain kiss } 1 \text { and kiss2 expression } \\
\text { (adult females) }\end{array}$ & Carnevali et al. (111) \\
\hline & Inhibits & Sea bass & Spring/LP & Melatonin implants downregulate brain kiss1 and kiss2 expression & Alvarado et al. (115) \\
\hline \multirow[t]{6}{*}{ Dopamine } & Inhibits & European eel & Spring/LP & Melatonin implants stimulate brain tyrosine hydroxylase activity & Sébert et al. (116) \\
\hline & & Carp & Spring/LP & Melatonin inhibits dopamine release in cultured hypothalamus & Popek (118) \\
\hline & & & & Melatonin injections inhibit brain dopamine release & Popek et al. (119) \\
\hline & & Asian catfish & Spring/LP & $\begin{array}{l}\text { Melatonin inhibits hypothalamic tyrosine hydroxylase activity during preovulatory } \\
\text { phase in female }\end{array}$ & Chaube and Joy (120) \\
\hline & & & & A higher dose of melatonin has no effect on tyrosine hydroxylase activity & $\begin{array}{l}\text { Senthilkumaran } \\
\text { and Joy (121) }\end{array}$ \\
\hline & & Rainbow trout & Autumn/SP & Melatonin decreases hypothalamic-pituitary dopamine turnover & $\begin{array}{l}\text { Hernández-Rauda et al. } \\
\text { (122) }\end{array}$ \\
\hline
\end{tabular}

$11 \mathrm{KT}$ ) levels, thus impairing sexual maturation (115). Servili and collaborators (128) show that in sea bass, the non-hypophysiotropic Gnrh2 neurons send their projections to the pineal gland, and directly stimulate melatonin secretion. Taken together, these results suggest that melatonin in male sea bass, downregulates the production of the hypophysiotropic Gnrh forms (Gnrh1 and Gnrh3) and their release in the pituitary. This, combined with the reduction of Gnrh receptors in the pituitary, result in gonadotropin downregulation. The use of different concentrations of exogenous melatonin can modulate its effects on Gnrh and gonadotropin content. For example, in underyearling masu salmon (Oncorhynchus masou), oral administration of melatonin (50 $\mu \mathrm{g} / \mathrm{g}$ feed) under LP increases Fsh and T plasma content but has no effect on Lh (129), suggesting that mimicking SP by melatonin administration stimulates testicular development. However, a 10 -fold higher dose $(500 \mu \mathrm{g} / \mathrm{g}$ feed $)$ decreases pituitary Gnrh and Lh content together with plasma T levels (113). In contrast, the Gnrh system does not respond to melatonin in some teleost species such as European eel (Anguilla anguilla) where melatonin implants had no effects on brain gnrh1 and gnrh2 mRNA levels (116).

The specific pathways through which melatonin affects Gnrh are largely unknown. In sea bass, the effects of melatonin on Gnrh neuron activity are most likely mediated via interneurons (114), since the distribution of melatonin receptors does not match the distribution of gnrh1 and gnrh3 cells (106). In masu salmon, melatonin binding sites were localized in the POA (113), however no colocalization study was performed to investigate their presence in Gnrh neurons.

\section{Gnih}

Melatonin modulates the activity of Gnih neurons by stimulating or inhibiting Gnih expression in different species. In adult zebrafish females, exogenous melatonin treatment reduces gnih mRNA levels in cultured whole brain, while DD decreases in vivo brain gnih and increases both $l h b$ and $f_{s} h b$ mRNA in the pituitary (117). In contrast, in Nile tilapia (mixed sex), brain gnih mRNA levels increase during the night, in parallel with plasma melatonin levels in mature fish (130). Additionally, intraperitoneal melatonin injections increase gnih and mtnrlc mRNA in the brain and simultaneously decrease $l h b$ and $f$ sh $b$ mRNA in the pituitary.

Kim and colleagues (130) suggest that, like in birds, melatonin might act on Gnih neuron activity via Mtnr1c (131). Indeed, in the cinnamon clownfish (Amphiprion melanopus), Gnih neurons express Mtnr1c (named from the authors MT-R1) (132). However, whether this is a species-specific case, or a general condition for all teleosts, remains to be investigated.

\section{Kiss}

In teleosts, contrary to in mammals, Kiss neurons directly regulate pituitary endocrine cells rather than acting through Gnrh neurons (133). Teleosts possess two genes encoding kisspeptins (kiss1, kiss2) $(16,134)$. Melatonin is also involved in the control of kiss expression in teleosts. In adult female zebrafish, melatonin exposure via immersion increases mRNA transcript levels of both kiss 1 and kiss 2 in the brain, and $l h b$ in the pituitary (111). While kiss 1 does not respond to photoperiod manipulations, kiss 2 mRNA is induced under LL when melatonin plasma levels are at their minimum 
(117). In contrast to in zebrafish, prolonged exposure to melatonin via implants decreases brain mRNA levels of kiss 1 and kiss 2 in male sea bass (115). The heterogeneity of kiss response, as seen for $g n r h$, highlight the influence of experimental conditions and suggest the possible involvement of different pathways influenced by the hormonal and nervous photoperiodic signal.

It is not known whether melatonin acts directly on kiss neurons or operates via interneurons in teleosts. In sea bass, Kiss1 and Kiss2 immunoreactive neurons were identified in the lateral tuberal nucleus and parvocellular nucleus, respectively (135), two locations that also express melatonin receptors (106). However, a clear colocalization of the melatonin receptors in Kiss neurons has not been demonstrated.

\section{Dopamine}

In several teleost species, dopaminergic neurons from the POA exert a strong negative control on gonadotropes, especially Lh-producing cells (82). Melatonin, in turn, influences the activity of hypophysiotropic dopaminergic neurons. In European eel melatonin implants stimulate the dopaminergic system in the POA, increasing tyrosine hydroxylase activity, the rate-limiting enzyme of dopamine synthesis (116). As a consequence, this treatment downregulates both $l h b$ and fshb mRNA levels. In contrast to the eel, melatonin inhibits the dopaminergic system in other fish species. For instance, in mature female carp (Cyprinus carpio), melatonin decreases dopamine release, both in in vitro cultured hypothalamus (118) and in vivo by direct injection into the third cerebral ventricle (119). The in vivo inhibition of dopamine release was registered during the spawning period in summer, but not during sexual regression in winter, suggesting that the effect of melatonin on the dopaminergic system might depend of the maturation stage. Inhibiting effects of melatonin on the dopaminergic systems were also observed in other species, including the threespot wrasse (Halichoeres trimaculatus), where intraperitoneal melatonin injections downregulate brain dopamine content (136), and rainbow trout (Oncorhynchus mykiss), where melatonin decreases the hypothalamic-pituitary dopamine turnover (122). In preovulatory female catfish (Heteropneustes fossilis), melatonin injections for three days inhibit tyrosine hydroxylase enzymatic activity in the hypothalamus (120). However, in a previous study using the same species, reproductive phase and melatonin injection dose, but administrated over a longer period (20 days), failed to affect hypothalamic dopamine turnover (121). This indicates that the length of the treatment with melatonin might affect the response of the dopaminergic system.

Melatonin binding and $m t n r$ mRNA distribution studies in rainbow trout (108) indicate that it is very unlikely that Mtnr is present on hypophysiotropic dopaminergic neurons. Therefore, the effects of melatonin might be mediated by interneurons in this species. Studies in Atlantic salmon (137) goldfish (Carassius auratus) (138) and Japanese catfish (Silurus asotus) (139), identify melatonin binding sites in the POA, where hypophysiotropic dopaminergic neurones are located (82); however, a clear colocalization has not been demonstrated.

\section{Summary}

Melatonin affects pituitary hormonal production in both mammals and teleosts by regulating upstream brain factors. As gonadotropes play a crucial role in the control of reproduction, which often depends on environmental conditions, it is not surprising that especially their response to indirect melatonin signaling has been studied extensively.

In mammals, melatonin modulates gonadotropin expression by acting on POA/hypothalamic signaling centers. It downregulates KISS and GnRH production and stimulate dopaminergic activity in summer breeders, while it upregulates KISS and GnRH production and inhibits dopaminergic activity in winter breeders. Interestingly, melatonin reduces $\mathrm{GnIH}$ neuronal activity in both summer and winter breeders, indicating downstream differences in the signaling cascade.

In teleost fish, melatonin affects these brain signaling hubs in a more complex manner, both inhibiting and activating the gonadotrope axis, depending on the species. In some species, melatonin activates the gonadotrope axis by simultaneously stimulating the production of Gnrh and Kiss, while inhibiting Gnih; in others, melatonin exerts a negative action on reproduction. Melatonin may downregulate dopamine production resulting in increased gonadotropin synthesis, or it can stimulate the dopaminergic system and inhibit gonadotropin production. Nevertheless, in both teleosts and mammals, a clear picture of the cell types directly targeted by melatonin in the brain is still scarce. In light of such opposing forces, it is urgent to identify the specific cell types targeted by melatonin in both mammals and teleosts, by determining which ones express MTNR. This is a requirement before being able to fully elucidate the mechanisms involved in the integration of environmental signals in the brain neuroendocrine centers.

\section{DIRECT EFFECTS OF MELATONIN ON THE ANTERIOR PITUITARY}

\section{Mammals}

In addition to the effects mediated by the brain, melatonin can act directly on the pituitary gland in mammals (Figure 3, Table 3).

\section{Melatonin Receptors in Mammalian Pituitary}

The main target for melatonin within the mammalian pituitary is the PT, as indicated by the important presence of melatonin binding sites in all mammalian species investigated so far. Those include, for instance, Siberian hamster (154, 155); Syrian hamster, (154-156); rat, (154, 155, 157, 158); red deer (Cervus elaphus) (159); ferret (Mustela putorius furo) (160), rhesus monkeys (Macaca mulatta) (161) and human (89). MTNR1A (MT1) is the main form of melatonin receptor present in the PT. Mtnrla mRNA was detected by in situ hybridization in the PT of sheep, Siberian hamster and rat (154) and in primary PT cell cultures of sheep (162). MTNR1A has also been detected in human PT, via immunostaining (89). Identification of the specific cell types expressing melatonin receptors is a key requisite to discriminate the direct effects mediated by melatonin. Double labelling combining in situ hybridization and immunohistochemistry shows that Mtnrla is expressed in most, but not all, thyrotrope cells within the PT, while it is absent from the other endocrine cells types in the anterior 
TABLE 3 | Summary of the known effects of melatonin on pituitary in vitro and ex vivo cultures in mammals.

\begin{tabular}{|c|c|c|c|}
\hline Species & Type of preparation & Effects of melatonin & Reference \\
\hline \multicolumn{4}{|l|}{ Mammals } \\
\hline \multirow[t]{6}{*}{ Sheep } & PT cell culture & Acute: inhibits forskolin-induced secretion of tuberalin & Morgan et al. (140) \\
\hline & PT cell culture & Acute: inhibits forskolin-induced cAMP & Hazlerigg et al. (141) \\
\hline & PT cell culture & Prolonged: increase basal and forskolin-induced cAMP & Hazlerigg et al. (141) \\
\hline & PT cell culture & Reduces Mtnr1a mRNA & Barret et al. (142) \\
\hline & PT explants & Reduces Mtnr1a mRNA & Fustin et al. (143) \\
\hline & PT explants and cell culture & Reduces Egr1 expression & Fustin et al. (143) \\
\hline \multirow[t]{4}{*}{ Rat (neonatal) } & PD organ cultures & Inhibits LH and FSH release & $\begin{array}{l}\text { Martin and Klein (144) } \\
\text { Martin and Sattler (145) }\end{array}$ \\
\hline & PD cell culture & Inhibits GnRH-induced Ca2+ signal and LH secretion & Vaněček and Klein (146) \\
\hline & PD cell culture & Inhibits GnRH-induced cFOS & Sumova et al. (147) \\
\hline & Organ cultures & No effect on TRH-induced TSH/PRL or SRIF-induced inhibition of GH & $\begin{array}{l}\text { Martin and Klein (144) } \\
\text { Martin and Sattler (145) }\end{array}$ \\
\hline Rat (maturing) & PD cell culture & No effect on GnRH-response & Rivest et al. (148) \\
\hline \multirow[t]{3}{*}{ Rat (Adult) } & TP/ME explants & Inhibits Lh release & Nakazawa et al. (149) \\
\hline & $\mathrm{GH} 3 / \mathrm{GH} 4$ cell line & Inhibits secretion of PRL and GH (no effect on cAMP) & Griffiths et al. (150) \\
\hline & GH3 cell line & Inhibits basal and forskolin-induced PRL secretion and expression & Ogura-Ochi et al. (151) \\
\hline Baboon & PD cell culture & No effect on LH or FSH secretion & lbáñez-Costa et al. (152) \\
\hline \multirow[t]{3}{*}{ Baboon } & PD cell culture & Stimulates $\mathrm{GH}$ and $\mathrm{PRL}$ expression and release & lbáñez-Costa et al. (152) \\
\hline & PD cell culture & Increases expression of receptors for $\mathrm{GhRH}$ and ghrelin, decreases receptors for somatostatin & lbáñez-Costa et al. (152) \\
\hline & PD cell culture & No effect on ACTH or TSH & lbáñez-Costa et al. (152) \\
\hline Mouse & ATt20 cell line & Inhibits cAMP and ACTH release & Tsukamoto et al. (153) \\
\hline
\end{tabular}

pituitary in European hamster (Cricetus cricetus) (163) and rat (157). This suggests that thyrotropes of the PT are the main pituitary target of melatonin action in mammalian species.

Interestingly, the expression of Mtnr within the PT varies across the year, in response to different neuroendocrine factors (34), modulating the endocrine response to melatonin between the different seasons. For instance, Mtnr expression increases during the reproductive season, peaking under LP in summer breeders or SP in winter breeders. Simulating winter season in the summer breeder Syrian hamster, using artificial SP (164) or melatonin injections $(156,165)$ induces a marked decrease in MTNR density in the PT of Syrian hamster. Melatonin injections decrease MTNR1A density in both Syrian and Siberian hamster PT (156). Similar effects of SP were shown in European hamster $(163,166)$ and hedgehog, Erinaceus europaeus (167). On the contrary, in winter breeders such as the mink (Mustela vison), the density of melatonin binding sites in the PT plummets in July and peaked in October, in concomitance with reactivation of sexual activity (168).

Melatonin and the pituitary also regulate daily physiological rhythms. As a consequence, variations in the presence of MTNR within the PT are not limited to annual cycles, but also occur within the span of a single day. Mtnrla mRNA levels vary during the day in the PT of Siberian and Syrian hamster, peaking during daytime and decreasing at night (156).

Finally, in the PD of foetal rat, Mtnrla mRNA was also identified by in situ hybridization before activation of the GnRH system, but not in postnatal stages (169). Bae and colleagues (170) demonstrate that Mtnrla transcripts are present in the mice $\alpha \mathrm{T} 3-1$ gonadotrope cell line, but their expression is downregulated after exposure to GnRH. The activation of the $\mathrm{GnRH}$ system in postnatal stages might therefore be responsible for the lack of MTNR in the adult PD reported in rat. Melatonin binding sites were also detected in the PD of adult sheep (171,
172), red deer (159) and ferret (160). A weak staining of MTNR1A was detected in human PD by in situ hybridization (89). To date, the identity of the cellular targets of melatonin within the PD and their contribution to the hormonal regulation of the gland remain largely unknown.

\section{Effects of Melatonin on the Pars Tuberalis}

As mentioned above, melatonin pituitary binding primarily takes place in the PT. Through these cells, melatonin seems to regulate the $\mathrm{PD}$ activity via at least two different routes, a retrograde route from the PT to the brain (Figure 5) and an anterograde route from the PT to the PD, as discussed below.

\section{Retrograde Route}

Studies in rodents demonstrate the inhibitory effects of melatonin on PT-TSH synthesis (173) via MTNR1A (174). During the long days in spring/summer, PT-TSH rises independently from TRH stimulation (175) due to reduced circulating melatonin levels. In the retrograde route (Figure 5), the expression of PT-TSH is rapidly induced, after LP exposure, by the transcription factor EYA3, which works with the circadian transcription factor thyrotroph embryonic factor (TEF) $(176,177)$. Melatonin acutely inhibits Eya3 expression, but at the same time induces a peak of Eya3 $12 \mathrm{~h}$ later. This leads to a strong morning peak of Eya3 (and subsequently TSH) during long days. Although several other collaborating transcription factors are involved in the precise circannual regulation of TSH secretion from PT, EYA3 seems to be the one regulated by photoperiod via melatonin.

PT-TSH then reaches the brain where it binds to its receptors in tanycytes, specialized ependymal cells within the mediobasal hypothalamus, thus regulating the enzymatic activity of local deiodinases (Dio2-Dio3) $(173,178)$. This controls local thyroid hormone (TH) metabolism by converting thyroxine (T4) to the bioactive triiodothyroxine (T3), serving as key regulator of 


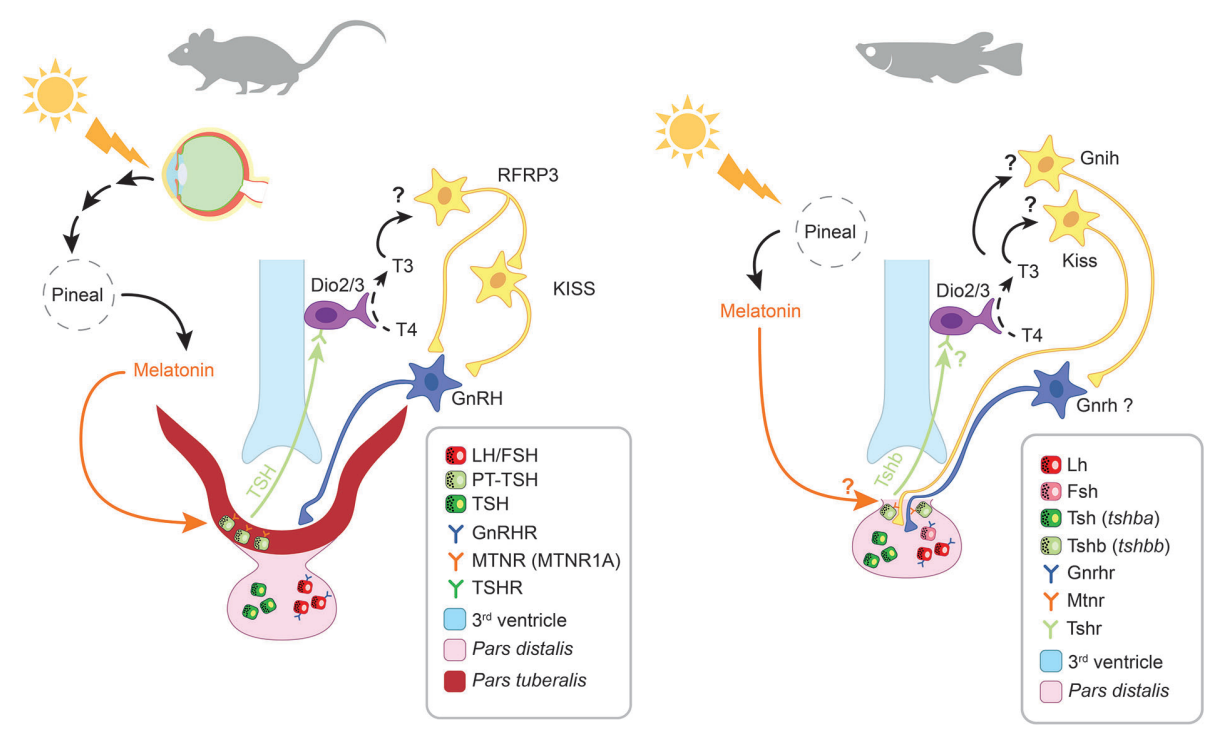

FIGURE 5 | Melatonin-induced retrograde signaling in mammals and teleosts. Thyrotrope and gonadotrope cells are respectively represented as green and red squares (see legend). Question marks (?) indicate putative pathways not yet demonstrated. In mammals, the photic signal perceived from the retina reaches the pineal gland after being processed from different brain centers (including the suprachiasmatic nucleus, SCN) thus regulating the rhythmic release of melatonin at night. Circulating melatonin acts on pars tuberalis (PT) thyrotropes (PT-TSH) via MTRN1A, thus inhibiting PT-TSH release. In spring, when melatonin levels decrease, PT-TSH secretion is stimulated. PTTSH, guided by tissue specific glycosylation, binds on its receptors on tanycytes located in the third ventricle of the hypothalamus. Here, PT-TSH regulates local deiodinases (Dio2/Dio3) influencing thyroid hormone metabolism by promoting the conversion of T4 into the bioactive T3. T3 in turn activates arcuate nucleus (ARC) kisspeptin (KISS) neurons via a still unknown mechanism. The following increase in gonadotropin releasing hormone (GnRH) release, stimulates gonadotropes activity in the pars distalis (PD). In teleosts the photic signal is directly perceived from photoreceptive structures within the pineal gland, thus regulating the rhythmic release of melatonin at night. Recent studies suggest that melatonin might regulate the release of a retrograde signal from the pituitary also in teleosts. A distinct population of thyrotrope cells (expressing a second Tsh paralogue, tshbb) located near the pituitary stalk, drastically increase tshbb expression under long photoperiod, a similar response to the one occurring in mammalian PT-TSH. Although melatonin receptors have been described in teleost pituitary and found to display daily and seasonal regulation, their presence in this thyrotrope population as well as the inhibition of Tsh synthesis and release in response to melatonin, remain to be demonstrated.

seasonality (173). Ikegami and collaborators (175) demonstrate that specific post-translational glycosylations allow PT-TSH to exclusively target the hypothalamus, and not the thyroid. While the cellular and molecular targets remain to be clearly identified, recent findings indicate that the increase of T3 in the mediobasal hypothalamus acts on KISS1 and RFRP3 neurons, which in turn modulate GnRH secretion (78). The molecular pathway from melatonin to $\mathrm{T} 3$ production appears to be conserved in mammalian species regardless of their reproductive strategy as summer or winter breeders $(67,179)$. Therefore, species-specific differences might occur downstream of this common pathway.

\section{Anterograde Route}

In the anterograde route, melatonin regulates PRL synthesis and secretion in the PD by inhibiting the release from the PT of one or more PRL-releasing factors named "tuberalin" (67). To date, the PT-specific factor(s) are still undetermined, as more than 30 different factors are known to stimulate PRL secretion (92). Several candidates have been proposed including tachykinin-1 and neurokinin A in sheep (180) or endocannabinoids in hamster $(179,181)$. Notably, these factors might act through folliculo-stellate cells to regulate lactotropes (182).

Tuberalin secretion can indeed be stimulated in ovine PT cell cultures by forskolin (140), an activator of adenylyl cyclase (AC), the enzyme catalysing the conversion of ATP to cyclic AMP (cAMP). The forskolin-induced secretion of tuberalin from PT cells was assessed by adding medium from the PT culture to a PD culture and measuring the amount of PRL secreted in response. Melatonin acutely inhibited the forskolin-induced secretion of tuberalin but had no effect alone. In support, melatonin inhibited the forskolin-induced cAMP production in ovine PT cells (141). Furthermore, melatonin downregulated the expression of its own receptor in PT cells from rat (183) and sheep (142). In ovine PT cells, the downregulation of Mtnr expression involves the cAMP signaling pathway (143). Together, these results imply that melatonin works through the MTNR/Gi/cAMP pathway to inhibit tuberalin secretion and subsequently regulating PRL production in the PD. Interestingly, incubation with melatonin for $16 \mathrm{~h}$ sensitizes $\mathrm{AC}$, increasing both basal and forskolininduced cAMP production (141). After the prolonged melatonin exposure, acute application of melatonin still inhibits the forskolin-induced cAMP increase.

For melatonin to inhibit secretion of tuberalin, there must be a stimulating factor that melatonin can oppose. This "tuberalin releasing factor" has not been identified but was named StimX by Morgan and Williams (184). Dardente and colleagues (67) proposed dopamine as a promising candidate for StimX, arguing that it might act through the dopamine receptor D1 expressed in PT 
cells, whose activation increases the intracellular cAMP level in neurons.

Downstream of cAMP, melatonin up-regulates or downregulates the expression of a range of genes (67). Several of them are clock genes, including Period1 (Per1) and Cryptochrome-1 (Cry1) (185). This implies that PT cell activity might be regulated by an internal clock and that the clock itself may be modulated by melatonin. Interestingly, the same clock genes are not affected by melatonin in the suprachiasmatic nucleus (SCN) of the hypothalamus, indicating that the SCN clock is working more independently than peripheral clocks (186-188). In ovine PT cell cultures and explants, the expression of the immediate early gene Egrl is acutely suppressed by melatonin, which otherwise follows a daily rhythm (143). EGR1 in turn regulates several genes, some being upregulated, such as Cry1, others downregulated such as Mrnt1a. In contrast to Mtnrla, the expression of Cry1 was not affected by changes in cAMP levels.

Other PT endocrine cells beside thyrotropes might also be regulated by melatonin. Nakazawa and collaborators (149) found that melatonin inhibits $\mathrm{LH}$ release from male rat tissue explants (consisting of PT and median eminence) in a dose-dependent manner. This in turn increases the release of $\mathrm{GnRH}$ from the median eminence part of the explant.

\section{Effects of Melatonin on the pars distalis Gonadotropes}

In rodents, the effects on $\mathrm{PD}$ gonadotropes seem highly age-specific, with clear inhibitory effects in neonatal animals and no effects in adults. Melatonin (1-10 nM) reduces the GnRH-induced LH and FSH release in pituitary organ cultures from neonatal rats (144, 145). Furthermore, Vanecek and Klein (146) demonstrate that melatonin $(10 \mathrm{nM})$ reduces the $\mathrm{GnRH}$-induced $\mathrm{Ca}^{2+}$ signal and subsequently LH secretion. Similarly, Pelisek and Vanecek (189) demonstrated that melatonin $(2 \mathrm{nM})$ reduces $\mathrm{GnRH}$-induced $\mathrm{LH}$ release, as well as the forskolin-induced cAMP production, in cell cultures from neonatal rats. Melatonin (1 nM) directly inhibits GnRH-induced $\mathrm{Ca}^{2+}$ signaling in neonatal gonadotropes, both via plasma membrane $\mathrm{Ca}^{2+}$ channels and endoplasmic reticulum $\mathrm{Ca}^{2+}$ release channels (190). The inhibitory effect of melatonin on the GnRH-induced $\mathrm{Ca}^{2+}$ oscillations might not be uniform over the gonadotrope cell population as the responses differ between cells, indicating a complex regulatory pathway $(191,192)$. The role of MTNR in neonatal PD may not be limited to gonadotrope regulation. In light of the previously described role of melatonin on the regulation of clock genes, Johnston and colleagues (169) suggest that Mtnrla expression may reflect a developmental requirement for circadian synchronization between tissues before mature regulatory pathways become established. Additionally, the promoter region of rat Mtnrla contains response elements for transcription factors involved in pituitary cell differentiation and regulation (169). Melatonin might therefore be involved in the correct development of the embryonic PD. Indeed, melatonin (100 $\mathrm{nM}$ ) inhibits $\mathrm{GnRH}$-induced increase of $c$ Fos (a proto-oncogene involved in cellular proliferation and differentiation) immunoreactivity in neonatal rat pituitary PD culture (147).

During development and maturation, melatonin binding is reduced, and in adults, melatonin does not have the same direct effect on the pituitary. Rivest and collaborators (148) found that melatonin incubation (5 $\mathrm{nM}$ ) of pituitary cell cultures from sexually maturing rats does not modify the $\mathrm{GnRH}$ response. Likewise, Ibáñez-Costa and colleagues (152) found no effect of melatonin ( $\mathrm{pM}$ to $\mu \mathrm{M}$ range) on the $\mathrm{FSH}$ and $\mathrm{LH}$ secretion in primary pituitary cultures from adult female baboons.

\section{Other Endocrine Cells in the pars distalis}

Regarding the effects of melatonin on other PD endocrine cells, the results are even scarcer. Melatonin $\left(10^{-8}\right.$ to $\left.10^{-6} \mathrm{M}\right)$ reduces the production and secretion of both PRL and GH from the rat pituitary cell line GH4C1, but has no effect on basal or stimulated cAMP levels (150). Similarly, Ogura-Ochi and collaborators (151) show that melatonin suppresses both basal and forskolin-induced PRL secretion and mRNA abundance in the closely related GH3 cell line. In contrast, in primary pituitary cell cultures from adult female baboons, melatonin increases GH and PRL expression and release in a dose-dependent manner, an effect blocked by somatostatin (152). Both the common (AC/PKA/Ca-channels) and distinct (PLC/Ca-release) pathways seem to be involved. Melatonin (10 $\mathrm{nM}$ ) also affects the expression of GHRH receptors, ghrelin and somatostatin, but not expression or release of ACTH or TSH. Also in pituitary organ cultures from neonatal rats, melatonin has no effect on TRH-induced TSH/PRL release or somatostatin-induced inhibition of GH release $(144,145)$. In the mice corticotrope cell line AtT20, melatonin reduces the levels of ACTH, alongside a reduction in cAMP (153).

\section{Teleosts}

As in mammals, melatonin can also act directly on the pituitary gland in teleosts (Figure 4, Table 4).

\section{Melatonin Receptors in Teleosts Pituitary}

Multiple Mtnr paralogues are expressed in the pituitary of teleosts (28). For instance, qPCR analysis detected the mRNA of four Mtnr paralogues in the pituitary of medaka (27). Three were described in Senegalese sole (Solea senegalensis) (200), goldfish (201), and Atlantic salmon (25). Two were detected in chum salmon (Oncorhynchus keta) (202) and pike (Esox lucius) (196). One was detected in European sea bass (203), suggesting possible multiple effects of melatonin which might also vary between species.

The exact location of melatonin receptor/binding sites in teleosts is not clear. Despite the aforementioned identification of $m t n r$ mRNA in goldfish pituitary, Martinoli and colleagues (107) observe no specific binding of melatonin. On the other hand, rainbow trout (197) and pike (196) pituitaries have 2-[ $\left.{ }^{125} \mathrm{I}\right]$ iodo-melatonin binding sites. However, the assay used was aimed at characterizing the binding capacity rather than their localization within the pituitary, although a regional distribution was reported, with binding sites clustering together in close proximity.

Like in mammals, the abundance of pituitary Mtnr in teleosts varies with the season and the day, suggesting a correlation with physiological state. The Senegalese sole (200) shows seasonal fluctuations with higher mtnr mRNA levels during the summer spawning period. While a first study in Atlantic salmon carried out in autumn indicated the absence of melatonin binding sites 
TABLE 4 | Summary of the known effects of melatonin on pituitary in vitro and ex vivo cultures in teleosts.

\begin{tabular}{|c|c|c|c|}
\hline Species & Type of preparation & Effects of melatonin & Reference \\
\hline \multicolumn{4}{|l|}{ Teleosts } \\
\hline \multirow[t]{2}{*}{ Goldfish } & Primary cell culture & No effect on AC activity & Deery et al. (193) \\
\hline & Perfused fragments & No effect on secretion of Lh, Fsh or Gh. & Somoza and Peter (194) \\
\hline European eel & Primary cell culture & No effect on fshb and lhb mRNA levels & Sébert et al. (116) \\
\hline Atlantic croaker & Perfused fragments & Stimulates Lh (Gthll) secretion & Khan and Thomas (195) \\
\hline Pike & Whole pituitary & Inhibits forskolin-induced cAMP & Gaildrat and Falcón (196) \\
\hline \multirow[t]{3}{*}{ Rainbow trout } & Primary cell culture & Low dose: inhibits forskolin-induced cAMP and Gh secretion & Falcón et al. (197) \\
\hline & Primary cell culture & High dose: stimulates Gh secretion & Falcón et al. (197) \\
\hline & Primary cell culture & High dose: inhibits Prl secretion & Falcón et al. (197) \\
\hline European sea bass & Primary cell culture & Increases Cry1 and Cry2 mRNA levels & Herrero and Lepesant (198) \\
\hline Medaka & Whole pituitary organ culture & Reduces fshb, tshb and s/ mRNA levels (not Ihb, gh, prl or pomc) & Kawabata-Sakata et al. (199) \\
\hline
\end{tabular}

(137), a later study shows that Mtnr exhibits both seasonal and daily fluctuations in the male parr pituitary (25). In spring during sexual maturation, pituitary mtnr mRNA peaks during the day and drops at night, while in autumn minimal levels are constantly maintained throughout the day. In medaka, where SP inhibits reproduction, pituitary $m t n r 1 a, m t n r 1 c$, and $m t n r 1 d$, but not $m t n r 1 b$ mRNA levels show daily fluctuations with higher levels at night under LP but not SP (27). The presence of multiple Mtnr paralogues whose concentrations vary across the season indicates a complex role of melatonin in teleost pituitary physiology. It is not yet clear precisely which cell types express $m t n r$ in teleosts. Indeed, the seasonal and daily variations in $m t n r$ mRNA levels observed in sole, sea bass, salmon, and medaka suggest a relation with the reproductive status of the fish. These fluctuations also highlight the importance of both the timing of sampling and the application of different techniques for the successful identification of the cells expressing Mtnr within the pituitary.

\section{Effects of Melatonin in Teleosts Pituitary Putative Retrograde Signal}

Unlike mammals, teleosts do not possess an anatomically distinct PT. Nakane and Yoshimura (204) propose that, in salmonids, the translation of the photoperiodic signals into pituitary hormonal messages might instead take place in the saccus vasculosus (SV), a secretory organ located posterior to the pituitary and directly connected to the third ventricle of the hypothalamus. In masu salmon, specialized cells within the SV, the coronet cells, possess all the components involved in the regulation of seasonal reproduction via the Tsh pathway (Tsh $\beta$, Tsh receptors and Dio2). However, the exact photoperiodic role of the SV (and the involvement of melatonin in it), remains controversial. First, the SV signal pathway is presumably directly activated by photo-transduction through photoreceptive pigments without the requirement of melatonin (205). Additionally a recent study in juvenile Atlantic salmon reported no photoperiodic effects on SV tsh $b$ and dio2b mRNA levels (206). Finally, the SV is not present in all fish [e.g. it is absent in zebrafish $(207,208)]$. Therefore, a different mechanism might be involved in the photoperiodic control of seasonality in fish.

Several teleosts possess two tsh $b$ paralogues resulting from the 3R, $t s h b a$ and $t s h b b$ (209) (named by the authors $t \operatorname{sh} \beta$ and $t \operatorname{sh} \beta 3$ ). In Atlantic salmon, both are expressed in the pituitary, but only $t s h b b$ is expressed in the SV (210). Interestingly, while pituitary tshba mRNA levels are relatively constant, tsh $b b$ mRNA level vary profoundly, with a peak concomitant with the onset of downstream migration, in spring. Since the two paralogs also show expression at distinct locations in the pituitary, Fleming and colleagues (210) propose that $t$ shbb-expressing cells, located near the pituitary stalk, are analogous to the mammalian PTTSH cells and possibly regulate the retrograde diffusion of Tsh to the hypothalamus (Figure 5).

Irachi and collaborators (206) demonstrate a significant increase in pituitary $t s h b b$ mRNA levels followed by a rise in dio $2 b$ mRNA levels in the midbrain/optic tectum and hypothalamus in response to increased daylength, providing additional evidence that the pituitary Tshb (formed by the tshbb subunit) is a key contributor to photoperiodic signaling in fish, similar to the mammalian PTTSH. However, whether like in mammals, melatonin signal is directly integrated by the pituitary Tshb (tshbb-expressing) cells in teleosts, is not known.

\section{Other Endocrine Cells in the Pars Distalis}

The direct effects of melatonin on other endocrine cell types have not been extensively investigated in teleosts and the few studies available indicate different effects between species.

In goldfish, melatonin $\left(10^{-6}-10^{-3} \mathrm{M}\right)$ has no effect on AC activity in homogenized pituitary samples (193). Although AC is part of the most common signaling pathway triggered by melatonin receptors, this result does not rule out the possibility that melatonin may trigger effects via other pathways. The conclusion that melatonin most probably had no direct effect on the pituitary was further supported by a study on perfused goldfish pituitary fragments, from which melatonin did not affect secretion of gonadotropins or Gh (194). Similarly, Sébert and colleagues (116) report from unpublished in vitro experiments that melatonin has no effect on $f_{s h} b$ and $l h b$ mRNA levels in primary pituitary cultures from European eel.

However, effects of melatonin have been observed in other species. Melatonin $(0.2 \mathrm{ng} / \mathrm{ml})$ stimulates Lh (GtH II) secretion from pituitary fragments from mature Atlantic croaker (195). In trout pituitary organ- and cell cultures, high concentration of melatonin [close to the night-time circulating levels as determined by Gern and colleagues (211)] induces a dosedependent Gh secretion in the absence of forskolin, along with a decrease in the secretion of $\operatorname{Prl}$ (197). In contrast, low melatonin 
concentration (close to daytime circulating levels) inhibits the forskolin-induced increase in cAMP levels and Gh secretion. Finally, melatonin exposure $\left(10^{-5} \mathrm{M}\right)$ in ex vivo whole pituitary organ culture from sexually mature medaka, decreases $f$ sh $b, t s h a$ and $s l$ mRNA levels but has no significant effects on $l h b, g h$, prl, and pomc, (199).

\section{Summary}

The presence of melatonin receptors indicates that melatonin can directly regulate pituitary cells. According to the receptor localization, the PT thyrotropes are the main targets of melatonin in the mammalian pituitary. A few mammalian species also have melatonin binding sites in the PD, suggesting a possible direct control of melatonin on $\mathrm{PD}$ endocrine production. The teleost pituitary also expresses several Mtnr paralogues, however their localization is not clear.

In mammals, most of the direct effects of melatonin on the pituitary take place in the $\mathrm{PT}$, in particular on thyrotropes (Figure 5). Here, melatonin acting via MTNR1A (MT1) affects the expression levels of a set of clock genes that in turn regulate synthesis and secretion of TSH and the hitherto unidentified tuberalin, for retrograde and anterograde seasonal regulation of gonadotropes and lactotropes in the $\mathrm{PD}$, respectively. The signaling pathway from MTNR1A activation to transcriptional regulation seems to mainly be via inhibition of AC/cAMP and possibly CREB. Studies on the direct effects of melatonin in the PD are still scarce, but there is solid evidence that melatonin inhibits $\mathrm{LH}$ secretion from $\mathrm{PD}$ gonadotropes in neonatal stage, but not in adults.

Fewer studies on the direct effects of melatonin on the teleost pituitary have been performed. They report different effects depending on the species and the experimental conditions. Nevertheless, recent works described a new pituitary Tsh population responding to variation in photoperiod similarly to PT-TSH in mammals, suggesting that a Tsh retrograde signaling might also occur in teleosts. It is therefore crucial that future research investigate the presence of melatonin receptors and the responsiveness to melatonin in this cell type to verify whether, similar to in mammals, melatonin signal is directly integrated by Tshb (tshbb-expressing) cells in teleosts.

\section{DISCUSSION}

As shown in the present review, the response of the pituitary to melatonin is highly plastic and differs between seasons, time of the day, physiological status, and reproductive strategies. The comparison between mammals and teleosts reveals a greater knowledge gap in the latter group, leaving many open questions on the role of melatonin in regulating the pituitary hormonal production. In both mammals and teleosts however, the exact pathways and cell types targeted by melatonin are largely unknown. It is therefore crucial to clearly describe the integration of the melatonin signal, and identify the cell types expressing melatonin receptors, in the pituitary as well as in the brain. Multicolor in situ hybridization or immuno-labelling and single cell transcriptomic approaches are relevant techniques that can be applied to identify the cell types directly targeted by melatonin.
To validate the effects of melatonin on the different cell types a combination of in vivo, ex vivo and in vitro studies will be necessary, as no single approach can produce a complete and reliable picture by itself. For instance, caution should be taken when investigating dissociated endocrine pituitary cells in culture, as a recent study shows that dissociation leads to a quick cellular phenotypic change in the pituitary cells (212). Additionally, when deciding on animal model and experimental conditions, one should also consider the important biological differences that might influence, or be influenced by, a time-keeping hormone as melatonin, such as nocturnal versus diurnal habits, different reproductive seasons or hibernation periods. Indeed, the response in animals adapted during numerous generations to stable laboratory conditions, such as mice, rats, zebrafish and medaka, might diverge from the ones in the wild.

In addition, given the seasonality of the processes regulated by melatonin, the localization of MTNR appears to be heavily influenced by factors such as physiological status, season, but also time of the day. It is therefore reasonable to assume that the expression of MTNR in some key cell types might be characteristic of specific physiological conditions and might still remain undetected when analyzed outside a particular time window.

Finally, when investigating the effects of melatonin on neuroendocrine system activity, teleosts show a remarkable plasticity as their response is more sensitive to variation in environmental conditions as compared to mammals $(1,213)$. As a consequence, it is harder to draw a general picture of the role of melatonin on teleosts brain and pituitary, as the choice of the season or the time of the day to perform the experiment appear to influence the response of the pituitary gland in teleosts.

Because of this sheer number of physiological and environmental variables, as well as significant inter-specific variation, unravelling the full impact of melatonin on the pituitary gland remains a challenge.

\section{AUTHOR CONTRIBUTIONS}

EC, TH, and RF contributed to the conception and design of the review. All authors contributed to the article and approved the submitted version.

\section{FUNDING}

This work was supported by the Norwegian University of Life Sciences (NMBU), Ås, Norway, and the University of Oslo (UiO), Oslo, Norway, with the support of the Marie Curie Alumni Association.

\section{ACKNOWLEDGMENTS}

The authors are grateful to Anthony Peltier for the illustrations (Figures 1, 2, and 5) and to Dr. Christiaan Henkel for having reviewed our manuscript. 


\section{REFERENCES}

1. Falcón J, Zohar Y. Photoperiodism in fish. In: Encyclopedia of Reproduction. New York (USA): Elsevier (2018). p. 400-8. doi: 10.1016/B978-0-12-8096338.20584-0

2. Reiter RJ, Tan D-X, Sharma R. Historical Perspective and Evaluation of the Mechanisms by which Melatonin Mediates Seasonal Reproduction in Mammals. Melatonin Res (2018) 1(1):59-77. doi: 10.32794/mr11250004

3. Reiter RJ. Melatonin: The chemical expression of darkness. Mol Cell Endocrinol (1991) 79(1-3):C153-8. doi: 10.1016/0303-7207(91)90087-9

4. Falcón J. Cellular circadian clocks in the pineal. Prog Neurobiol (1999) 58 (2):121-62. doi: 10.1016/S0301-0082(98)00078-1

5. Klein DC, Coon SL, Roseboom PH, Weller JL, Bernard M, Gastel JA, et al. The Melatonin Rhythm-generating Enzyme: Molecular Regulation of Serotonin N-acetyltransferase in the Pineal Gland. Recent Prog Horm Res (1997) 52:307-57.

6. Klein DC. Arylalkylamine N-acetyltransferase: “The timezyme.” J Biol Chem (2007) 282(7):4233-7. doi: 10.1074/jbc.R600036200

7. Klein DC. The 2004 aschoff/pittendrigh lecture: Theory of the origin of the pineal gland - A tale of conflict and resolution. J Biol Rhythms (2004) 19 (4):264-79. doi: 10.1177/0748730404267340

8. Klein DC. Evolution of the vertebrate pineal gland: The AANAT hypothesis. Chronobiol Int (2006) 23(1-2):5-20. doi: 10.1080/07420520500545839

9. Falcón J, Coon SL, Besseau L, Cazaméa-Catalan D, Fuentès M, Magnanou E, et al. Drastic neofunctionalization associated with evolution of the timezyme AANAT 500 Mya. Proc Natl Acad Sci USA (2014) 111(1):314-9. doi: 10.1073/ pnas. 1312634110

10. Putnam NH, Butts T, Ferrier DEK, Furlong RF, Hellsten U, Kawashima T, et al. The amphioxus genome and the evolution of the chordate karyotype. Nature (2008) 453(7198):1064-71. doi: 10.1038/nature06967

11. Simakov O, Marlétaz F, Yue JX, O'Connell B, Jenkins J, Brandt A, et al. Deeply conserved synteny resolves early events in vertebrate evolution. Nat Ecol Evol (2020) 4(6):820-30. doi: 10.1038/s41559-020-1156-Z

12. Dehal P, Boore JL. Two rounds of whole genome duplication in the ancestral vertebrate. PLoS Biol (2005) 3(10):e314. doi: 10.1371/journal.pbio.0030314

13. Amores A, Force A, Yan YL, Joly L, Amemiya C, Fritz A, et al. Zebrafish hox clusters and vertebrate genome evolution. Science (80- ) (1998) 282 (5394):1711-4. doi: 10.1126/science.282.5394.1711

14. Allendorf FW, Thorgaard GH. Tetraploidy and the Evolution of Salmonid Fishes. In: Evolutionary Genetics of Fishes. Boston, MA: Springer US (1984). p. 1-53. doi: 10.1007/978-1-4684-4652-4_1

15. Ohno S, Muramoto J, Christian L, Atkin NB. Diploid-tetraploid relationship among old-world members of the fish family Cyprinidae. Chromosoma (1967) 23(1):1-9. doi: 10.1007/BF00293307

16. Dufour S, Quérat B, Tostivint H, Pasqualini C, Vaudry H, Rousseau K. Origin and Evolution of the Neuroendocrine Control of Reproduction in Vertebrates, With Special Focus on Genome and Gene Duplications. Physiol Rev (2020) 100(2):869-943. doi: 10.1152/physrev.00009.2019

17. Li J, You X, Bian C, Yu H, Coon SL, Shi Q. Molecular evolution of aralkylamine n-acetyltransferase in fish: A genomic survey. Int J Mol Sci (2015) 17(1):51. doi: 10.3390/ijms17010051

18. Cazaméa-Catalan D, Besseau L, Falcón J, Magnanou E. The timing of timezyme diversification in vertebrates. PLoS One (2014) 9(12):112380. doi: 10.1371/journal.pone.0112380

19. Coon SL, Klein DC. Evolution of arylalkylamine N-acetyltransferase: emergence and divergence. Mol Cell Endocrinol (2006) 252(1-2):2-10. doi: 10.1016/j.mce.2006.03.039

20. Paulin CH, Cazaméa-Catalan D, Zilberman-Peled B, Herrera-Perez P, Sauzet S, Magnanou E, et al. Subfunctionalization of arylalkylamine $\mathrm{N}$-acetyltransferases in the sea bass Dicentrarchus labrax: two-ones for one two. J Pineal Res (2015) 59(3):354-64. doi: 10.1111/jpi.12266

21. Borjigin J, Li X, Snyder SH. The pineal gland and melatonin: molecular and pharmacologic regulation. Annu Rev Pharmacol Toxicol (1999) 39:53-65. doi: 10.1146/annurev.pharmtox.39.1.53

22. Bayarri MJ, Rol de Lama MA, Madrid JA, Sanchez-Vazquez FJ. Both pineal and lateral eyes are needed to sustain daily circulating melatonin rhythms in sea bass. Brain Res (2003) 969(1-2):175-82. doi: 10.1016/s0006-8993(03)02297-2
23. Muñoz-Pérez JL, López-Patiño MA, Álvarez-Otero R, Gesto M, Soengas JL Míguez JM. Characterization of melatonin synthesis in the gastrointestinal tract of rainbow trout (Oncorhynchus mykiss): distribution, relation with serotonin, daily rhythms and photoperiod regulation. J Comp Physiol B Biochem Syst Environ Physiol (2016) 186(4):471-84. doi: 10.1007/s00360-016-0966-4

24. Brydon L, Petit L, de Coppet P, Barrett P, Morgan PJ, Strosberg AD, et al. Polymorphism and signalling of melatonin receptors. Reprod Nutr Dev (1999) 39(3):315-24. doi: 10.1051/rnd:19990304

25. Ciani E, Fontaine R, Maugars G, Mizrahi N, Mayer I, Levavi-Sivan B, et al. Melatonin receptors in Atlantic salmon stimulate cAMP levels in heterologous cell lines and show season-dependent daily variations in pituitary expression levels. J Pineal Res (2019) 67(3):e12590. doi: 10.1111/jpi.12590

26. Denker E, Ebbesson LOE, Hazlerigg DG, Macqueen DJ. Phylogenetic reclassification of vertebrate melatonin receptors to include Mel1d. G3 (Bethesda) (2019) 9(10):3225-38. doi: 10.1534/g3.119.400170

27. Sakai K, Yamamoto Y, Ikeuchi T. Vertebrates originally possess four functional subtypes of $\mathrm{G}$ protein-coupled melatonin receptor. Sci Rep (2019) 9(1):9465. doi: 10.1038/s41598-019-45925-2

28. Maugars G, Nourizadeh-lillabadi R, Weltzien F-A, Nourizadeh-Lillabadi R, Weltzien F-A. New insights into the evolutionary history of melatonin receptors in vertebrates, with particular focus on teleosts. Front Endocrinol (Lausanne) (2020) 11:538196. doi: 10.3389/fendo.2020.538196

29. Rimler A, Jockers R, Lupowitz Z, Sampson SR, Zisapel N. Differential effects of melatonin and its downstream effector PKC $\alpha$ on subcellular localization of RGS proteins. J Pineal Res (2006) 40(2):144-52. doi: 10.1111/j.1600079X.2005.00290.x

30. Gaildrat P, Becq F, Falcón J. First cloning and functional characterization of a melatonin receptor in fish brain: a novel one? J Pineal Res (2002) 32(2):7484. doi: 10.1034/j.1600-079x.2002.1817.x

31. Vaněček J. Cellular mechanisms of melatonin action. Physiol Rev (1998) 78 (3):687-721. doi: 10.1152/physrev.1998.78.3.687

32. Huang H, Lee SC, Yang XL. Modulation by melatonin of glutamatergic synaptic transmission in the carp retina. J Physiol (2005) 569(3):857-71. doi: 10.1113/jphysiol.2005.098798

33. Dubocovich ML, Delagrange P, Krause DN, Sugden D, Cardinali DP, Olcese J. Nomenclature, Classification, and Pharmacology of G Protein-Coupled Melatonin Receptors. Pharmocological Rev (2010) 62(3):343-80. doi: 10.1124/ pr.110.002832.343

34. Witt-Enderby PA, Bennett J, Jarzynka MJ, Firestine S, Melan MA. Melatonin receptors and their regulation: biochemical and structural mechanisms. Life Sci (2003) 72(20):2183-98. doi: 10.1016/S0024-3205(03)00098-5

35. Kelberman D, Rizzoti K, Lovell-Badge R, Robinson IC, Dattani MT. Genetic regulation of pituitary gland development in human and mouse. Endocr Rev (2009) 30(7):790-829. doi: 10.1210/er.2009-0008

36. Pogoda HM, Hammerschmidt M. Molecular genetics of pituitary development in zebrafish. Semin Cell Dev Biol (2007) 18(4):543-58. doi: 10.1016/j.semcdb.2007.04.004

37. Yamamoto K, Bloch S, Vernier P. New perspective on the regionalization of the anterior forebrain in Osteichthyes. Dev Growth Differ (2017) 59(4):17587. doi: $10.1111 /$ dgd. 12348

38. Fabian P, Tseng K-C, Smeeton J, Lancman JJ, Dong PDS, Cerny R, et al. Lineage analysis reveals an endodermal contribution to the vertebrate pituitary. Science (80- ) (2020) 370(6515):463-7. doi: 10.1126/science.aba4767

39. Zhu X, Gleiberman AS, Rosenfeld MG. Molecular physiology of pituitary development: Signaling and transcriptional networks. Physiol Rev (2007) 87 (3):933-63. doi: 10.1152/physrev.00006.2006

40. Weltzien FA, Andersson E, Andersen $\varnothing$, Shalchian-Tabrizi K, Norberg B The brain-pituitary-gonad axis in male teleosts, with special emphasis on flatfish (Pleuronectiformes). Comp Biochem Physiol - A Mol Integr Physiol (2004) 137(3):447-77. doi: 10.1016/j.cbpb.2003.11.007

41. Zohar Y, Muñoz-Cueto JA, Elizur A, Kah O. Neuroendocrinology of reproduction in teleost fish. Gen Comp Endocrinol (2010) 165(3):438-55. doi: 10.1016/j.ygcen.2009.04.017

42. Kaprara A, Huhtaniemi IT. The hypothalamus-pituitary-gonad axis: Tales of mice and men. Metabolism (2018) 86:3-17. doi: 10.1016/j.metabol.2017.11.018

43. Fontaine R, Ciani E, Haug TM, Hodne K, Ager-Wick E, Baker DM, et al. Gonadotrope plasticity at cellular, population and structural levels: A 
comparison between fishes and mammals. Gen Comp Endocrinol (2020) 287:113344. doi: 10.1016/j.ygcen.2019.113344

44. Fontaine R, Royan MR, von Krogh K, Weltzien F, Baker D. Direct and indirect effects of sex steroids on gonadotrope cell plasticity in the teleost fish pituitary. Front Endocrinol (Lausanne) (2020) 11:605068. doi: 10.3389/ fendo.2020.605068

45. Bittman EL, Kaynard AH, Olster DH, Robinson JE, Yellon SM, Karsch FJ. Pineal melatonin mediates photoperiodic control of pulsatile luteinizing hormone secretion in the ewe. Neuroendocrinology (1985) 40(5):409-18. doi: $10.1159 / 000124106$

46. Viguié C, Caraty A, Locatelli A, Malpaux B. Regulation of Luteinizing Hormone-Releasing Hormone (LHRH) Secretion by Melatonin in the Ewe.I. Simultaneous Delayed Increase in LHRH and Luteinizing Hormone Pulsatile Secretion1. Biol Reprod (1995) 52(5):1114-20. doi: 10.1095/ biolreprod52.5.1114

47. El Qandil S, Chakir J, El Moussaouiti R, Oukouchoud R, Rami N, Benjelloun WA, et al. Role of the pineal gland and melatonin in the photoperiodic control of hypothalamic gonadotropin-releasing hormone in the male jerboa (Jaculus orientalis), a desert rodent. Brain Res Bull (2005) 64(5):371-80. doi: 10.1016/j.brainresbull.2004.06.010

48. Roy D, Angelini NL, Fujieda H, Brown GM, Belsham DD. Cyclical regulation of GnRH gene expression in GT1-7 GnRH-secreting neurons by melatonin. Endocrinology (2001) 142(11):4711-20. doi: 10.1210/endo. 142.11 .8464

49. Sato S, Yin C, Teramoto A, Sakuma Y, Kato M. Sexually dimorphic modulation of GABAA receptor currents by melatonin in rat gonadotropin-releasing hormone neurons. J Physiol Sci (2008) 58(5):31722. doi: 10.2170/physiolsci.RP006208

50. Revel FG, Ansel L, Klosen P, Saboureau M, Pévet L, Mikkelsen JD, et al. Kisspeptin: A key link to seasonal breeding. Rev Endocr Metab Disord (2007) 8(1):57-65. doi: 10.1007/s11154-007-9031-7

51. Ansel L, Bolborea M, Bentsen AH, Klosen P, Mikkelsen JD, Simonneaux V. Differential regulation of kiss1 expression by melatonin and gonadal hormones in male and female syrian hamsters. J Biol Rhythms (2010) 25 (2):81-91. doi: 10.1177/0748730410361918

52. Piekarski DJ, Jarjisian SG, Perez L, Ahmad H, Dhawan N, Zucker I, et al. Effects of pinealectomy and short day lengths on reproduction and neuronal RFRP-3, kisspeptin, and GnRH in female Turkish hamsters. J Biol Rhythms (2014) 29(3):181-91. doi: 10.1177/0748730414532423

53. Li SN, Xue HL, Zhang Q, Xu JH, Wang S, Chen L, et al. Photoperiod regulates the differential expression of KISS-1 and GPR54 in various tissues and sexes of striped hamster. Genet Mol Res (2015) 14(4):13894-905. doi: 10.4238/2015.October.29.10

54. Oliveira AC de, Andreotti S, Sertie RAL, Campana AB, de Proença ARG, Vasconcelos RP, et al. Combined treatment with melatonin and insulin improves glycemic control, white adipose tissue metabolism and reproductive axis of diabetic male rats. Life Sci (2018) 199:158-66. doi: 10.1016/j.lfs.2018.02.040

55. Mason AO, Duffy S, Zhao S, Ubuka T, Bentley GE, Tsutsui K, et al. Photoperiod and reproductive condition are associated with changes in RFamide-Related Peptide (RFRP) expression in Syrian hamsters (Mesocricetus auratus). J Biol Rhythms (2010) 25(3):176-85. doi: 10.1177/ 0748730410368821

56. Revel FG, Saboureau M, Pévet P, Simonneaux V, Mikkelsen JD. RFamiderelated peptide gene is a melatonin-driven photoperiodic gene. Endocrinology (2008) 149(3):902-12. doi: 10.1210/en.2007-0848

57. Ubuka T, Inoue K, Fukuda Y, Mizuno T, Ukena K, Kriegsfeld LJ, et al. Identification, expression, and physiological functions of Siberian hamster gonadotropin-inhibitory hormone. Endocrinology (2012) 153(1):373-85. doi: 10.1210/en.2011-1110

58. Alexiuk NAM, Uddin M, Vriend J. Melatonin increases the in situ activity of tyrosine hydroxylase in the mediobasal hypothalamus of male Syrian hamsters. Life Sci (1996) 59(8):687-94. doi: 10.1016/0024-3205(96)00350-5

59. Viguié C, Thibault J, Thiéry J-CC, Tillet Y, Malpaux B. Characterization of the short day-induced decrease in median eminence tyrosine hydroxylase activity in the ewe: Temporal relationship to the changes in luteinizing hormone and prolactin secretion and short day-like effect of melatonin. Endocrinology (1997) 138(1):499-506. doi: 10.1210/endo.138.1.4865
60. Hastings MH, Walker AP, Roberts AC, Herbert J. Intra-hypothalamic melatonin blocks photoperiodic responsiveness in the male syrian hamster. Neuroscience (1988) 24(3):987-91. doi: 10.1016/0306-4522(88)90081-4

61. Lincoln GA, Maeda KI. Effects of placing micro-implants of melatonin in the mediobasal hypothalamus and preoptic area on the secretion of prolactin and $\beta$-endorphin in rams. J Endocrinol (1992) 134(3):437-48. doi: 10.1677/ joe.0.1340437

62. Malpaux B, Daveau A, Maurice F, Gayrard V, Thiery J-C. Short-Day Effects of Melatonin on Luteinizing Hormone Secretion in the Ewe: Evidence for Central Sites of Action in the Mediobasal Hypothalamus1. Biol Reprod (1993) 48(4):752-60. doi: 10.1095/biolreprod48.4.752

63. Maywood ES. Lesions of the iodomelatonin-binding sites of the mediobasal hypothalamus spare the lactotropic, but block the gonadotropic response of male Syrian hamsters to short photoperiod and to melatonin. Endocrinology (1995) 136(1):144-53. doi: 10.1210/en.136.1.144

64. Bae HH, Mangels RA, Cho BS, Dark J, Yellon SM, Zucker I. Ventromedial hypothalamic mediation of photoperiodic gonadal responses in male Syrian hamsters. J Biol Rhythms (1999) 14(5):391-401. doi: 10.1177/074873099 129000795

65. Lewis D, Freeman DA, Dark J, Wynne-Edwards KE, Zucker I. Photoperiodic control of oestrous cycles in Syrian hamsters: Mediation by the mediobasal hypothalamus. J Neuroendocrinol (2002) 14(4):294-9. doi: 10.1046/j.13652826.2002.00779.x

66. Vivid D, Bentley GE. Seasonal Reproduction in Vertebrates: Melatonin Synthesis, Binding, and Functionality Using Tinbergen's Four Questions. Molecules (2018) 23(3):652. doi: 10.3390/molecules 23030652

67. Dardente H, Wood S, Ebling F, Sáenz de Miera C. An integrative view of mammalian seasonal neuroendocrinology. J Neuroendocrinol (2019) 31(5): e12729. doi: 10.1111/jne.12729

68. Ciani E, Fontaine R, Maugars G, Nourizadeh-Lillabadi R, Andersson E, Bogerd J, et al. Gnrh receptor gnrhr2bbo is expressed exclusively in lhbexpressing cells in Atlantic salmon male parr. Gen Comp Endocrinol (2020) 285:113293. doi: 10.1016/j.ygcen.2019.113293

69. Stewart AJ, Katz AA, Millar RP, Morgan K. Retention and silencing of prepro-GnRH-II and type II GnRH receptor genes in mammals. Neuroendocrinology (2009) 90(4):416-32. doi: 10.1159/000233303

70. Roy D, Belsham DD. Melatonin receptor activation regulates $\mathrm{GnRH}$ gene expression and secretion in GT1-7 GnRH neurons. Signal transduction mechanisms. J Biol Chem (2002) 277(1):251-8. doi: 10.1074/jbc.M108890200

71. Ishii H, Tanaka N, Kobayashi M, Kato M, Sakuma Y. Gene structures, biochemical characterization and distribution of rat melatonin receptors. J Physiol Sci (2009) 59(1):37-47. doi: 10.1007/s12576-008-0003-9

72. Kriegsfeld LJ, Mei DF, Bentley GE, Ubuka T, Mason AO, Inoue K, et al. Identification and characterization of a gonadotropin-inhibitory system in the brains of mammals. Proc Natl Acad Sci USA (2006) 103(7):2410-5. doi: 10.1073/pnas.0511003103

73. Ancel C, Bentsen AH, Sébert ME, Tena-Sempere M, Mikkelsen JD, Simonneaux V. Stimulatory effect of RFRP-3 on the gonadotrophic axis in the male Syrian hamster: The exception proves the rule. Endocrinology (2012) 153(3):1352-63. doi: 10.1210/en.2011-1622

74. Dardente H, Birnie M, Lincoln GA, Hazlerigg DG. RFamide-Related peptide and its cognate receptor in the sheep: cDNA cloning, mRNA distribution in the hypothalamus and the effect of photoperiod. J Neuroendocrinol (2008) 20 (11):1252-9. doi: 10.1111/j.1365-2826.2008.01784.x

75. Smith JT, Coolen LM, Kriegsfeld LJ, Sari IP, Jaafarzadehshirazi MR, Maltby M, et al. Variation in kisspeptin and RFamide-related peptide (RFRP) expression and terminal connections to gonadotropin-releasing hormone neurons in the brain: A novel medium for seasonal breeding in the sheep. Endocrinology (2008) 149(11):5770-82. doi: 10.1210/en.2008-0581

76. Harbid AA, Mcleod BJ, Caraty A, Anderson GM. Seasonal changes in RFamide-related peptide- 3 neurons in the hypothalamus of a seasonally breeding marsupial species, the brushtail possum (Trichosurus vulpecula). J Comp Neurol (2013) 521(13):3030-41. doi: 10.1002/cne.23328

77. Kriegsfeld LJ, Ubuka T, Bentley GE, Tsutsui K. Seasonal control of gonadotropin-inhibitory hormone $(\mathrm{GnIH})$ in birds and mammals. Front Neuroendocrinol (2015) 37:65-75. doi: 10.1016/j.yfrne.2014.12.001

78. Simonneaux V. A Kiss to drive rhythms in reproduction. Eur J Neurosci (2020) 51(1):509-30. doi: 10.1111/ejn.14287 
79. Rasri-Klosen K, Simonneaux V, Klosen P. Differential response patterns of kisspeptin and RFamide-related peptide to photoperiod and sex steroid feedback in the Djungarian hamster (Phodopus sungorus). J Neuroendocrinol (2017) 29(9). doi: 10.1111/jne.12529

80. Gingerich S, Wang X, Lee PKP, Dhillon SS, Chalmers JA, Koletar MM, et al. The generation of an array of clonal, immortalized cell models from the rat hypothalamus: analysis of melatonin effects on kisspeptin and gonadotropininhibitory hormone neurons. Neuroscience (2009) 162(4):1134-40. doi: 10.1016/ j.neuroscience.2009.05.026

81. Li Q, Rao A, Pereira A, Clarke IJ, Smith JT. Kisspeptin Cells in the Ovine Arcuate Nucleus Express Prolactin Receptor but not Melatonin Receptor. J Neuroendocrinol (2011) 23(10):871-82. doi: 10.1111/j.1365-2826.2011.02195.x

82. Dufour S, Sebert ME, Weltzien FA, Rousseau K, Pasqualini C. Neuroendocrine control by dopamine of teleost reproduction. J Fish Biol (2010) 76(1):129-60. doi: 10.1111/j.1095-8649.2009.02499.x

83. Angelousi A, Margioris AN, Tsatsanis C. ACTH Action on the Adrenal. In: Endotext. South Dartmouth (MA): MDText.com, Inc. (2020). http://www. ncbi.nlm.nih.gov/pubmed/25905342

84. Aoyama H, Mori N, Mori W. Anti-glucocorticoid effects of melatonin on adult rats. Pathol Int (1987) 37(6):1143-8. doi: 10.1111/j.1440-1827.1987.tb00431.x

85. Pierpaoli W, Maestroni GJM. Melatonin: a principal neuroimmunoregulatory and anti-stress hormone: its anti-aging effects. Immunol Lett (1987) 16 (3-4):355-61. doi: 10.1016/0165-2478(87)90169-6

86. Konakchieva R, Mitev Y, Almeida OF, Patchev VK. Chronic melatonin treatment and the hypothalamo-pituitary-adrenal axis in the rat: Attenuation of the secretory response to stress and effects on hypothalamic neuropeptide content and release. Biol Cell (1997) 89(9):587-96. doi: 10.1111/j.1768322x.1997.tb01036.x

87. Konakchieva R, Mitev Y, Almeida OFX, Patchev VK. Chronic melatonin treatment counteracts glucocorticoid-induced dysregulation of the hypothalamic-pituitary-adrenal axis in the rat. Neuroendocrinology (1998) 67(3):171-80. doi: 10.1159/000054312

88. Fischer S, Smolnik R, Herms M, Born J, Fehm HL. Melatonin Acutely Improves the Neuroendocrine Architecture of Sleep in Blind Individuals. J Clin Endocrinol Metab (2003) 88(11):5315-20. doi: 10.1210/jc.2003-030540

89. Wu YH, Zhou JN, Balesar R, Unmehopa U, Bao A, Jockers B, et al. Distribution of MT1 melatonin receptor immunoreactivity in the human hypothalamus and pituitary gland: Colocalization of MT1 with vasopressin, oxytocin, and corticotropin-releasing hormone. J Comp Neurol (2006) 499 (6):897-910. doi: 10.1002/cne.21152

90. Bernard V, Young J, Binart N. Prolactin - a pleiotropic factor in health and disease. Nat Rev Endocrinol (2019) 15(6):356-65. doi: 10.1038/s41574-0190194-6

91. Pellicer-Rubio MT, Boissard K, Forgerit Y, Pougnard JL, Bonné JL, Leboeuf B. Evaluation of hormone-free protocols based on the "male effect" for artificial insemination in lactating goats during seasonal anestrus. Theriogenology (2016) 85(5):960-9. doi: 10.1016/j.theriogenology.2015.11.005

92. Freeman ME, Kanyicska B, Lerant A, Nagy G. Prolactin: Structure, function, and regulation of secretion. Physiol Rev (2000) 80(4):1523-631. doi: 10.1152/ physrev.2000.80.4.1523

93. Molik E, Misztal T, Romanowicz K, Zieba D. Short-day and melatonin effects on milking parameters, prolactin profiles and growth-hormone secretion in lactating sheep. Small Rumin Res (2013) 109(2-3):182-7. doi: 10.1016/j.smallrumres.2012.10.006

94. Ponchon B, Lacasse P, Ollier S, Zhao X. Effects of photoperiod modulation and melatonin feeding around drying-off on bovine mammary gland involution. J Dairy Sci (2017) 100(10):8496-506. doi: 10.3168/jds.2016-12272

95. Sanchez-Barcelo EJ, Mediavilla MD, Zinn SA, Buchanan BA, Chapin LT, Tucker HA. Melatonin suppression of mammary growth in heifers. Biol Reprod (1991) 44(5):875-9. doi: 10.1095/biolreprod44.5.875

96. Dahl GE, Buchanan BA, Tucker HA. Photoperiodic effects on dairy cattle: A review. J Dairy Sci (2000) 83(4):885-93. doi: 10.3168/jds.S0022-0302(00)74952-6

97. Lincoln GA, Tortonese DJ. Does melatonin act on dopaminergic pathways in the mediobasal hypothalamus to mediate effects of photoperiod on prolactin secretion in the ram? Neuroendocrinology (1995) 62(5):425-33. doi: $10.1159 / 000127032$

98. Lincoln GA, Clarke IJ. Evidence that Melatonin Acts in the Pituitary Gland through a Dopamine-independent Mechanism to Mediate Effects of
Daylength on the Secretion of Prolactin in the Ram. J Neuroendocrinol (1995) 7(8):637-43. doi: 10.1111/j.1365-2826.1995.tb00802.x

99. Ranke MB, Wit JM. Growth hormone-past, present and future. Nat Rev Endocrinol (2018) 14(5):285-300. doi: 10.1038/nrendo.2018.22

100. Sarapura VD, Samuel MH. Thyroid-Stimulating Hormone. In: The Pituitary: Fourth Edition. New York (USA): Elsevier Inc (2017). p. 163-201. doi: 10.1016/B978-0-12-804169-7.00006-4

101. Gross DS. The mammalian hypophysial pars tuberalis: A comparative immunocytochemical study. Gen Comp Endocrinol (1984) 56(2):283-98. doi: 10.1016/0016-6480(84)90043-1

102. Sakai T, Inoue K, Kurosumi K. Light and Electron Microscopic Immunocytochemistry of TSH-like Cells Occurring in the Pars tuberalis of the Adult Male Rat Pituitary. Arch Histol Cytol (1992) 55(2):151-7. doi: 10.1679/aohc.55.151

103. Wittkowski W, Bergmann M, Hoffmann K, Pera F. Photoperiod-dependent changes in TSH-like immunoreactivity of cells in the hypophysial pars tuberalis of the Djungarian hamster, Phodopus sungorus. Cell Tissue Res (1988) 251(1):183-7. doi: 10.1007/BF00215463

104. Joseph-Bravo P, Jaimes-Hoy L, Uribe RM, Charli JL. TRH, the first hypophysiotropic releasing hormone isolated: Control of the pituitary-thyroid axis. J Endocrinol (2015) 226(2):T85-T100. doi: 10.1530/JOE-15-0124

105. Bockmann J, Böckers TM, Winter C, Wittkowski W, Winterhoff H, Deufel T, et al. Thyrotropin Expression in Hypophyseal Pars Tuberalis-Specific Cells is 3,5,3'-Triiodothyronine, Thyrotropin-Releasing Hormone, and Pit-1 Independent*. Endocrinology (1997) 138(3):1019-28. doi: 10.1210/ endo.138.3.5007

106. Herrera-Pérez P, Del Carmen Rendón M, Besseau L, Sauzet S, Falcón J, Muñoz-Cueto JA. Melatonin receptors in the brain of the European sea bass: An in situ hybridization and autoradiographic study. J Comp Neurol (2010) 518(17):3495-511. doi: 10.1002/cne.22408

107. Martinoli MG, Williams LM, Kah O, Titchener LT, Pelletier G. Distribution of central melatonin binding sites in the goldfish (Carassius auratus). Mol Cell Neurosci (1991) 2(1):78-85. doi: 10.1016/1044-7431(91)90042-m

108. Mazurais D, Brierley I, Anglade I, Drew J, Randall C, Bromage N, et al. Central melatonin receptors in the rainbow trout: Comparative distribution of ligand binding and gene expression. JComp Neurol (1999) 409(2):313-24. doi: 10.1002/ (SICI) 1096-9861(19990628)409:2<313::AID-CNE11>3.0.CO;2-1

109. Iversen M, Myhr AI, Wargelius A. Approaches for delaying sexual maturation in salmon and their possible ecological and ethical implications. J Appl Aquac (2016) 28(4):330-69. doi: 10.1080/10454438.2016.1212756

110. Burgerhout E, Lokman PM, van den Thillart GEEJM, Dirks RP. The timekeeping hormone melatonin: a possible key cue for puberty in freshwater eels (Anguilla spp.). Rev Fish Biol Fish (2019) 29(1):1-21. doi: 10.1007/s11160-0189540-3

111. Carnevali O, Gioacchini G, Maradonna F, Olivotto I, Migliarini B. Melatonin induces follicle maturation in danio rerio. Hansen IA, ed. PLoS One (2011) 6 (5):e19978. doi: 10.1371/journal.pone.0019978

112. Kim JH, Park JW, Jin YH, Kim DJ, Kwon JY. Effect of melatonin on GnIH precursor gene expression in Nile tilapia, Oreochromis niloticus. Biol Rhythm Res (2018) 49(2):303-13. doi: 10.1080/09291016.2017.1357336

113. Amano M, Iigo M, Ikuta K, Kitamura S, Okuzawa K, Yamada H, et al. Disturbance of plasma melatonin profile by high dose melatonin administration inhibits testicular maturation of precocious male masu salmon. Zoolog Sci (2004) 21 (1):79-85. doi: 10.2108/0289-0003(2004)21[79:DOPMPB]2.0.CO;2

114. Servili A, Herrera-Pérez P, Rendón M del C, Muñoz-Cueto JA. Melatonin inhibits GnRH-1, GnRH-3 and GnRH receptor expression in the brain of the European sea bass, Dicentrarchus labrax. Int J Mol Sci (2013) 14(4):7603-16. doi: 10.3390/ijms 14047603

115. Alvarado MV, Carrillo M, Felip A. Melatonin-induced changes in kiss/gnrh gene expression patterns in the brain of male sea bass during spermatogenesis. Comp Biochem Physiol -Part A Mol Integr Physiol (2015) 185:69-79. doi: 10.1016/ j.cbpa.2015.03.010

116. Sébert ME, Legros C, Weltzien FA, Malpaux B, Chemineau P, Dufour S. Melatonin activates brain dopaminergic systems in the eel with an inhibitory impact on reproductive function. J Neuroendocrinol (2008) 20(7):917-29. doi: $10.1111 / j .1365-2826.2008 .01744 . x$

117. Yumnamcha T, Khan ZA, Rajiv C, Devi SD, Mondal G, Sanjita Devi H, et al. Interaction of melatonin and gonadotropin-inhibitory hormone on the zebrafish 
brain-pituitary-reproductive axis. Mol Reprod Dev (2017) 84(5):389-400. doi: $10.1002 / \mathrm{mrd} .22795$

118. Popek W, Łuszczek-Trojnar E, Drąg-Kozak E, Fortuna-Wrońska D, Epler P. Effect of the pineal gland and melatonin on dopamine release from perifused hypothalamus of mature female carp during spawning and winter regression. Acta Ichthyol Piscat (2005) 35(2):65-71. doi: 10.3750/AIP2005.35.2.01

119. Popek W, Łuszczek-Trojnar E, Drąg-Kozak E, Rząsa J, Epler P. Effect of melatonin on dopamine secretion in the hypothalamus of mature female common carp, Cyprinus carpio L. Acta Ichthyol Piscat (2006) 36(2):135-41. doi: 10.3750/AIP2006.36.2.07

120. Chaube R, Joy KP. Effects of altered photoperiod and temperature, serotoninaffecting drugs, and melatonin on brain tyrosine hydroxylase activity in female catfish, Heteropneustes fossilis: A study correlating ovarian activity changes. J Exp Zool (2002) 293(6):585-93. doi: 10.1002/jez.10185

121. Senthilkumaran B, Joy KP. Effects of melatonin, p-chlorophenylalanine, and $\alpha$-methylparatyrosine on plasma gonadotropin level and ovarian activity in the catfish, Heteropneustes fossilis: A study correlating changes in hypothalamic monoamines. Fish Physiol Biochem (1995) 14(6):471-80. doi: $10.1007 / \mathrm{BF} 00004347$

122. Hernández-Rauda R, Miguez JM, Ruibal C, Aldegunde M. Effects of melatonin on dopamine metabolism in the hypothalamus and the pituitary of the rainbow trout, Oncorhynchus mykiss. J Exp Zool (2000) 287(6):440-4. doi: 10.1002/1097-010X(20001101)287:6<440::AID-JEZ5> 3.0.CO;2-S

123. Levavi-Sivan B, Bogerd J, Mañanós EL, Gómez A, Lareyre JJ. Perspectives on fish gonadotropins and their receptors. Gen Comp Endocrinol (2010) 165 (3):412-37. doi: 10.1016/j.ygcen.2009.07.019

124. Schulz RW, de França LR, Lareyre JJ, LeGac F, Chiarini-Garcia H, Nobrega RH, et al. Spermatogenesis in fish. Gen Comp Endocrinol (2010) 165(3):390411. doi: $10.1016 /$ j.ygcen.2009.02.013

125. Campos-Mendoza A, McAndrew BJ, Coward K, Bromage N. Reproductive response of Nile tilapia (Oreochromis niloticus) to photoperiodic manipulation; Effects on spawning periodicity, fecundity and egg size. Aquaculture (2004) 231 (1-4):299-314. doi: 10.1016/j.aquaculture.2003.10.023

126. Ridha MT, Cruz EM. Effect of light intensity and photoperiod on nile tilapia Oreochromis niloticus L. seed production. Aquac Res (2000) 31(7):609-17. doi: 10.1046/j.1365-2109.2000.00481.x

127. Bayarri MJ, Rodríguez L, Zanuy S, Madrid JA, Sánchez-Vázquez FJ, Kagawa H, et al. Effect of photoperiod manipulation on the daily rhythms of melatonin and reproductive hormones in caged European sea bass (Dicentrarchus labrax). Gen Comp Endocrinol (2004) 136(1):72-81. doi: 10.1016/j.ygcen. 2003.12.004

128. Servili A, Lethimonier C, Lareyre JJ, López-Olmeda JF, Sánchez-Vázquez FJ, $\mathrm{Kah} \mathrm{O}$, et al. The highly conserved gonadotropin-releasing hormone-2 form acts as a melatonin-releasing factor in the pineal of a teleost fish, the European sea bass Dicentrarchus labrax. Endocrinology (2010) 151 (5):2265-75. doi: 10.1210/en.2009-1207

129. Amano M, Iigo M, Ikuta K, Kitamura S, Yamada H, Yamamori K. Roles of melatonin in gonadal maturation of underyearling precocious male masu salmon. Gen Comp Endocrinol (2000) 120(2):190-7. doi: 10.1006/ gcen.2000.7547

130. Kim JH, Park JW, Kwon JY. Effects of exogenous melatonin on the reproductive activities of Nile tilapia, Oreochromis niloticus. Biol Rhythm Res (2018) 49(3):392-404. doi: 10.1080/09291016.2017.1366715

131. Tsutsui K, Ubuka T, Yin H, Osugi T, Ukena K, Bentley GE, et al. Discovery of gonadotropin-inhibitory hormone in a domesticated bird, its mode of action and functional significance. J Ornithol (2007) 148(Suppl 2):S515-S20. doi: 10.1007/ s10336-007-0225-2

132. Choi YJ, Habibi HR, Choi CY. Profiles of gonadotropin-inhibitory hormone and melatonin during the sex change and maturation of cinnamon clownfish, Amphiprion melanopus. Biochem Biophys Res Commun (2016) 475(2):189-93. doi: 10.1016/j.bbrc.2016.05.073

133. Somoza GM, Mechaly AS, Trudeau VL. Kisspeptin and GnRH interactions in the reproductive brain of teleosts. Gen Comp Endocrinol (2020) 298:113568. doi: 10.1016/j.ygcen.2020.113568

134. Pasquier J, Kamech N, Lafont AG, Vaudry H, Rousseau K, Dufour S. Molecular evolution of GPCRs: Kisspeptin/kisspeptin receptors. J Mol Endocrinol (2014) 52(3):101-17. doi: 10.1530/JME-13-0224
135. Escobar S, Servili A, Espigares F, Gueguen MM, Brocal I, Felip A, et al. Expression of Kisspeptins and Kiss Receptors Suggests a Large Range of Functions for Kisspeptin Systems in the Brain of the European Sea Bass. PLoS One (2013) 8(7):e70177. doi: 10.1371/journal.pone.0070177

136. Takemura A, Uchimura M, Shibata Y. Dopaminergic activity in the brain of a tropical wrasse in response to changes in light and hydrostatic pressure. Gen Comp Endocrinol (2010) 166(3):513-9. doi: 10.1016/j.ygcen.2010.01.001

137. Ekström P, Vaněček J. Localization of 2-[125I]lodomelatonin binding sites in the brain of the atlantic salmon, salmo salar L. Neuroendocrinology (1992) 55 (5):529-37. doi: 10.1159/000126166

138. Iigo M, Kobayashi M, Ohtani-Kaneko R, Hara M, Hattori A, Suzuki T, et al. Characteristics, day-night changes, subcellular distribution and localization of melatonin binding sites in the goldfish brain. Brain Res (1994) 644(2):21320. doi: 10.1016/0006-8993(94)91682-9

139. Iigo M, Sánchez-Vázquez FJ, Hara M, Ohtani-Kaneko R, Hirata K, Shinohara $\mathrm{H}$, et al. Characterization, guanosine 5'-O-(3-thiotriphosphate) modulation, daily variation, and localization of melatonin-binding sites in the catfish (Silurus asotus) brain. Gen Comp Endocrinol (1997) 108(1):45-55. doi: 10.1006/gcen.1997.6940

140. Morgan PJ, Webster CA, Mercer JG, Ross AW, Hazlerigg DG, MacLean A, et al. The ovine pars tuberalis secretes a factor(s) that regulates gene expression in both lactotropic and nonlactotropic pituitary cells. Endocrinology (1996) 137(9):4018-26. doi: 10.1210/endo.137.9.8756579

141. Hazlerigg DG, Gonzalez-Brito A, Lawson W, Hastings MH, Morgan PJ. Prolonged exposure to melatonin leads to time-dependent sensitization of adenylate cyclase and down-regulates melatonin receptors in pars tuberalis cells from ovine pituitary. Endocrinology (1993) 132(1):285-92. doi: 10.1210/ endo.132.1.7678217

142. Barrett P, Davidson G, Hazlerigg DG, Morris MA, Ross AW, Morgan PJ. Mel 1a melatonin receptor expression is regulated by protein kinase $\mathrm{C}$ and an additional pathway addressed by the protein kinase $\mathrm{C}$ inhibitor Ro 31-8220 in ovine pars tuberalis cells. Endocrinology (1998) 139(1):163-71. doi: 10.1210/endo.139.1.5699

143. Fustin JM, Dardente H, Wagner GC, Carter DA, Johnston JD, Lincoln GA, et al. Egr1 involvement in evening gene regulation by melatonin. FASEB $J$ (2009) 23(3):764-73. doi: 10.1096/fj.08-121467

144. Martin JE, Klein DC. Melatonin inhibition of the neonatal pituitary response to luteinizing hormone-releasing factor. Science (80- ) (1976) 191(4224):3012. doi: $10.1126 /$ science. 1108199

145. Martin JE, Sattler C. Selectivity of melatonin pituitary inhibition for luteinizing hormone-releasing hormone. Neuroendocrinology (1982) 34 (2):112-6. doi: 10.1159/000123287

146. Vaněček J, Klein DC. Melatonin inhibition of GnRH-induced LH release from neonatal rat gonadotroph: Involvement of Ca2+ not cAMP. Am J Physiol Endocrinol Metab (1995) 269(1 32-1). doi: 10.1152/ajpendo.1995.269.1.e85

147. Sumova A, Vaněcek J. Melatonin Inhibits GnRH-Induced Increase of cFOS Immunoreactivity in Neonatal Rat Pituitary. J Neuroendocrinol (1997) 9 (2):135-9. doi: 10.1046/j.1365-2826.1997.d01-1076.x

148. Rivest RW, Jaconi MEE, Gruaz N, Sizonenko PC, Aubert ML. Short-term and long-term effects of melatonin on GnRH-stimulated gonadotropin secretion in pituitaries of sexually maturing rats. Neuroendocrinology (1987) 46(5):379-86. doi: 10.1159/000124848

149. Nakazawa K, Marubayashi U, McCann SM. Mediation of the short-loop negative feedback of luteinizing hormone (LH) on LH-releasing hormone release by melatonin-induced inhibition of $\mathrm{LH}$ release from the pars tuberalis. Proc Natl Acad Sci USA (1991) 88(17):7576-9. doi: 10.1073/pnas.88.17.7576

150. Griffiths D, Bjoro T, Gautvik K, Haug E. Melatonin reduces the production and secretion of prolactin and growth hormone from rat pituitary cells in culture. Acta Physiol Scand (1987) 131(1):43-9. doi: 10.1111/j.1748-1716.1987.tb08203.x

151. Ogura-Ochi K, Fujisawa S, Iwata N, Komatsubara M, Nishiyama Y, Tsukamoto-Yamauchi N, et al. Regulatory role of melatonin and BMP-4 in prolactin production by rat pituitary lactotrope GH3 cells. Peptides (2017) 94:19-24. doi: 10.1016/j.peptides.2017.06.001

152. Ibáñez-Costa A, Córdoba-Chacón J, Gahete MD, Kineman RD, Castaño JP, Luque RM. Melatonin regulates somatotrope and lactotrope function through common and distinct signaling pathways in cultured primary pituitary cells from female primates. Endocrinology (2015) 156(3):1100-10. doi: 10.1210/en.2014-1819 
153. Tsukamoto N, Otsuka F, Ogura-Ochi K, Inagaki K, Nakamura E, Toma K, et al. Melatonin receptor activation suppresses adrenocorticotropin production via BMP-4 action by pituitary AtT20 cells. Mol Cell Endocrinol (2013) 375(1-2):1-9. doi: 10.1016/j.mce.2013.05.010

154. Reppert SM, Weaver DR, Ebisawa T. Cloning and characterization of a mammalian melatonin receptor that mediates reproductive and circadian responses. Neuron (1994) 13(5):1177-85. doi: 10.1016/0896-6273(94)90055-8

155. Weaver DR, Rivkees SA, Reppert SM. Localization and characterization of melatonin receptors in rodent brain by in vitro autoradiography. J Neurosci (1989) 9(7):2581-90. doi: 10.1523/jneurosci.09-07-02581.1989

156. Schuster C, Gauer F, Malan A, Recio J, Pévet P, Masson-Pévet M. The circadian clock, light/dark cycle and melatonin are differentially involved in the expression of daily and photoperiodic variations in mtl melatonin receptors in the Siberian and Syrian hamsters. Neuroendocrinology (2001) 74(1):55-68. doi: 10.1159/000054670

157. Klosen P, Bienvenu C, Demarteau O, Dardente H, Guerrero H, Pévet P, et al. The $\mathrm{mtl}$ melatonin receptor and ROR $\beta$ receptor are co-localized in specific TSHimmunoreactive cells in the pars tuberalis of the rat pituitary. $J$ Histochem Cytochem (2002) 50(12):1647-57. doi: 10.1177/002215540205001209

158. Williams LM, Morgan PJ. Demonstration of melatonin-binding sites on the pars tuberalis of the rat. J Endocrinol (1988) 119(1):R1-3. doi: 10.1677/joe.0.119R001

159. Williams LM, Hannah LT, Kyle CE, Adam CL. Central melatonin receptors in red deer (Cervus elaphus). Gen Comp Endocrinol (1996) 104(1):1-6. doi: 10.1006/gcen.1996.0134

160. Weaver DR, Reppert SM. Melatonin receptors are present in the ferret pars tuberalis and pars distalis, but not in brain. Endocrinology (1990) 127 (5):2607-9. doi: 10.1210/endo-127-5-2607

161. Weaver DR, Stehle JH, Stopa EG, Reppert SM. Melatonin receptors in human hypothalamus and pituitary: Implications for circadian and reproductive responses to melatonin. J Clin Endocrinol Metab (1993) 76 (2):295-301. doi: 10.1210/jcem.76.2.8381796

162. Barrett P, MacLean A, Davidson G, Morgan PJ. Regulation of the Mel la melatonin receptor mRNA and protein levels in the ovine pars tuberalis: Evidence for a cyclic adenosine 3',5'- monophosphate-independent Mel 1a receptor coupling and an autoregulatory mechanism of expression. Mol Endocrinol (1996) 10(7):892-902. doi: 10.1210/me.10.7.892

163. Dardente H, Klosen P, Pévet P, Masson-Pévet M. MT1 melatonin receptor mRNA expressing cells in the pars tuberalis of the European hamster: Effect of photoperiod. J Neuroendocrinol (2003) 15(8):778-86. doi: 10.1046/j.13652826.2003.01060.x

164. Gauer F, Masson-Pévet M, Pévet P. Seasonal regulation of melatonin receptors in rodent pars tuberalis: correlation with reproductive state. J Neural Transm (1994) 96(3):187-95. doi: 10.1007/BF01294786

165. Tamarkin L, Westrom WK, Hamill AI, Goldman BD. Effect of melatonin on the reproductive systems of male and female syrian hamsters: A diurnal rhythm in sensitivity to melatonin12. Endocrinology (1976) 99(6):1534-41. doi: 10.1210/endo-99-6-1534

166. Skene DJ, Masson-Pevet M, Pevet P. Seasonal changes in melatonin binding sites in the pars tuberalis of male european hamsters and the effect of testosterone manipulation. Endocrinology (1993) 132(4):1682-6. doi: 10.1210/endo.132.4. 8462468

167. Gauer F, Masson-Pévet M, Saboureau M, George D, Pévet P. Differential Seasonal Regulation of Melatonin Receptor Density in the Pars Tuberalis and the Suprachiasmatic Nuclei: A Study in the Hedgehog (Erinaceus europaeus, L.). J Neuroendocrinol (1993) 5(6):685-90. doi: 10.1111/j.1365-2826.1993.tb00540.x

168. Messager S, Caillol M, George D, Martinet L. Seasonal Variation Of Melatonin Binding Sites In The Pars Tuberalis of the Male Mink (Mustela vison). J Neuroendocrinol (1997) 9(7):523-8. doi: 10.1046/j.1365-2826.1997.d01-1122.x

169. Johnston JD, Messager S, Barrett P, Hazlerigg DG. Melatonin action in the pituitary: Neuroendocrine synchronizer and developmental modulator? J Neuroendocrinol (2003) 15(4):405-8. doi: 10.1046/j.1365-2826.2003.00972.x

170. Bae SE, Wright IK, Wyse C, Samson-Desvignes N, Le Blanc P, Laroche S, et al. Regulation of pituitary MT1 melatonin receptor expression by gonadotrophinreleasing hormone $(\mathrm{GnRH})$ and early growth response factor-1 (Egr-1): In vivo and in vitro studies. PLoS One (2014) 9(3):e90056. doi: 10.1371/journal.pone.0090056

171. Bittman EL, Weaver DR. The Distribution of Melatonin Binding Sites in Neuroendocrine Tissues of the Ewe1. Biol Reprod (1990) 43(6):986-93. doi: 10.1095/biolreprod43.6.986
172. Heiliwell RJA, Williams LM. Melatonin Binding Sites in the Ovine Brain and Pituitary: Characterization During the Oestrous Cycle. J Neuroendocrinol (1992) 4(3):287-94. doi: 10.1111/j.1365-2826.1992.tb00170.x

173. Ono H, Hoshino Y, Yasuo S, Watanabe M, Nakane Y, Murai A, et al. Involvement of thyrotropin in photoperiodic signal transduction in mice. Proc Natl Acad Sci USA (2008) 105(47):18238-42. doi: 10.1073/pnas.0808952105

174. Yasuo S, Yoshimura T, Ebihara S, Korf HW. Melatonin transmits photoperiodic signals through the MT1 melatonin receptor. J Neurosci (2009) 29(9):2885-9. doi: 10.1523/JNEUROSCI.0145-09.2009

175. Ikegami K, Liao XH, Hoshino Y, Ono H, Ota W, Ito Y, et al. Tissue-specific posttranslational modification allows functional targeting of thyrotropin. Cell Rep (2014) 9(3):801-9. doi: 10.1016/j.celrep.2014.10.006

176. Dardente H, Wyse CA, Birnie MJ, Dupré SM, Loudon ASI, Lincoln GA, et al. A molecular switch for photoperiod responsiveness in mammals. Curr Biol (2010) 20(24):2193-8. doi: 10.1016/j.cub.2010.10.048

177. Wood S, Loudon A. Clocks for all seasons: unwinding the roles and mechanisms of circadian and interval timers in the hypothalamus and pituitary. J Endocrinol (2014) 222(2):R39-59. doi: 10.1530/JOE-14-0141

178. Watanabe M, Yasuo S, Watanabe T, Yamamura T, Nakao N, Ebihara S, et al. Photoperiodic regulation of type 2 deiodinase gene in djungarian hamster: Possible homologies between avian and mammalian photoperiodic regulation of reproduction. Endocrinology (2004) 145(4):1546-9. doi: 10.1210/en.2003-1593

179. Korf HW. Signaling pathways to and from the hypophysial pars tuberalis, an important center for the control of seasonal rhythms. Gen Comp Endocrinol (2018) 258:236-43. doi: 10.1016/j.ygcen.2017.05.011

180. Dupré SM, Miedzinska K, Duval CV, Yu L, Goodman RL, Lincoln GA, et al. Identification of Eya3 and TAC1 as Long-Day Signals in the Sheep Pituitary. Curr Biol (2010) 20(9):829-35. doi: 10.1016/j.cub.2010.02.066

181. Yasuo S, Korf HW. The hypophysial pars tuberalis transduces photoperiodic signals via multiple pathways and messenger molecules. Gen Comp Endocrinol (2011) 172(1):15-22. doi: 10.1016/j.ygcen.2010.11.006

182. Wood S, Loudon A. The pars tuberalis: The site of the circannual clock in mammals? Gen Comp Endocrinol (2018) 258:222-35. doi: 10.1016/ j.ygcen.2017.06.029

183. Gauer F, Masson-Pévet M, Pévet P. Melatonin receptor density is regulated in rats pars tuberalis and suprachiasmatic nuclei by melatonin itself. Brain Res (1993) 602(1):153-6. doi: 10.1016/0006-8993(93)90256-M

184. Morgan PJ, Williams LM. The pars tuberalis of the pituitary: A gateway for neuroendocrine output. Rev Reprod (1996) 1(3):153-61. doi: 10.1530/ ror. 0.0010153

185. Dardente H. Does a melatonin-dependent circadian oscillator in the pars tuberalis drive prolactin seasonal rhythmicity? J Neuroendocrinol (2007) 19 (8):657-66. doi: 10.1111/j.1365-2826.2007.01564.x

186. Messager S, Ross AW, Barrett P, Morgan PJ. Decoding photoperiodic time through Per1 and ICER gene amplitude. Proc Natl Acad Sci USA (1999) 96 (17):9938-43. doi: 10.1073/pnas.96.17.9938

187. Poirel VJ, Boggio V, Dardente H, Pevet P, Masson-Pevet M, Gauer F. Contrary to other non-photic cues, acute melatonin injection does not induce immediate changes of clock gene mRNA expression in the rat suprachiasmatic nuclei. Neuroscience (2003) 120(3):745-55. doi: 10.1016/ S0306-4522(03)00344-0

188. Johnston JD, Tournier BB, Andersson H, Masson-Pévet M, Lincoln GA, Hazlerigg DG. Multiple effects of melatonin on rhythmic clock gene expression in the mammalian pars tuberalis. Endocrinology (2006) 147 (2):959-65. doi: 10.1210/en.2005-1100

189. Pelíšek V, Vaněček J. Different effects of melatonin pretreatment on cAMP and LH responses of the neonatal rat pituitary cells. J Pineal Res (2000) 28 (4):234-41. doi: 10.1034/j.1600-079X.2000.280406.x

190. Balik A, Kretschmannová K, Mazna P, Svobodová I, Zemková H. Melatonin action in neonatal gonadotrophs. Physiol Res (2004) 53 Suppl 1(SUPPL. 1): S153-66. http://www.biomed.cas.cz/physiolres.

191. Zemkova H, Vaněček J. Dual effect of melatonin on gonadotropin-releasinghormone-induced $\mathrm{Ca} 2+$ signaling in neonatal rat gonadotropes. Neuroendocrinology (2001) 74(4):262-9. doi: 10.1159/000054693

192. Zemková H, Vaněček J. Inhibitory effect of melatonin on gonadotropinreleasing hormone-induced Ca2+ Oscillations in pituitary cells of newborn rats. Neuroendocrinology (1997) 65(4):276-83. doi: 10.1159/000127185 
193. Deery DJ. Effect of catecholamines and synthetic mammalian hypothalamic hormones on the adenylyl cyclase activity of the pituitary of the teleost, Carassius auratus. Gen Comp Endocrinol (1975) 25(4):395-9. doi: 10.1016/00166480(75)90149-5

194. Somoza GM, Peter RE. Effects of serotonin on gonadotropin and growth hormone release from in vitro perifused goldfish pituitary fragments. Gen Comp Endocrinol (1991) 82(1):103-10. doi: 10.1016/0016-6480(91)90301-1

195. Khan IA, Thomas P. Melatonin influences gonadotropin II secretion in the Atlantic croaker (Micropogonias undulatus). Gen Comp Endocrinol (1996) 104(2):231-42. doi: 10.1006/gcen.1996.0166

196. Gaildrat P, Falcón J. Melatonin receptors in the pituitary of a teleost fish: mRNA expression, 2-[125I]iodomelatonin binding and cyclic AMP response. Neuroendocrinology (2000) 72(1):57-66. doi: 10.1159/000054571

197. Falcón J, Besseau L, Fazzari D, Attia J, Gaildrat P, Beauchaud M, et al. Melatonin modulates secretion of growth hormone and prolactin by trout pituitary glands and cells in culture. Endocrinology (2003) 144(10):4648-58. doi: 10.1210/en.2003-0707

198. Herrero MJ, Lepesant JM. Daily and seasonal expression of clock genes in the pituitary of the European sea bass (Dicentrarchus labrax). Gen Comp Endocrinol (2014) 208:30-8. doi: 10.1016/j.ygcen.2014.08.002

199. Kawabata-Sakata Y, Nishiike Y, Fleming T, Kikuchi Y, Okubo K. Androgendependent sexual dimorphism in pituitary tryptophan hydroxylase expression: relevance to sex differences in pituitary hormones. Proc Biol Sci (2020) 287(1928):20200713. doi: 10.1098/rspb.2020.0713

200. Confente F, Rendón MC, Besseau L, Falcón J, Muñoz-Cueto JA. Melatonin receptors in a pleuronectiform species, Solea senegalensis: Cloning, tissue expression, day-night and seasonal variations. Gen Comp Endocrinol (2010) 167(2):202-14. doi: 10.1016/j.ygcen.2010.03.006

201. Ikegami T, Azuma K, Nakamura M, Suzuki N, Hattori A, Ando H. Diurnal expressions of four subtypes of melatonin receptor genes in the optic tectum and retina of goldfish. Comp Biochem Physiol - A Mol Integr Physiol (2009) 152(2):219-24. doi: 10.1016/j.cbpa.2008.09.030

202. Shi Q, Ando H, Coon SL, Sato S, Ban M, Urano A. Embryonic and postembryonic expression of arylalkylamine $\mathrm{N}$-acetyltransferase and melatonin receptor genes in the eye and brain of chum salmon (Oncorhynchus keta). Gen Comp Endocrinol (2004) 136(3):311-21. doi: 10.1016/j.ygcen.2004.01.004

203. Sauzet S, Besseau L, Herrera Perez P, Covès D, Chatain B, Peyric E, et al. Cloning and retinal expression of melatonin receptors in the European sea bass, Dicentrarchus labrax. Gen Comp Endocrinol (2008) 157(2):186-95. doi: 10.1016/j.ygcen.2008.04.008

204. Nakane Y, Yoshimura T. Photoperiodic Regulation of Reproduction in Vertebrates. Annu Rev Anim Biosci (2019) 7:173-94. doi: 10.1146/annurevanimal-020518-115216
205. Nakane Y, Ikegami K, Iigo M, Ono H, Takeda K, Takahashi D, et al. The saccus vasculosus of fish is a sensor of seasonal changes in day length. Nat Commun (2013) 4(1):2108. doi: 10.1038/ncomms3108

206. Irachi S, Hall DJ, Fleming MS, Maugars G, Björnsson BT, Dufour S, et al. Photoperiodic regulation of pituitary thyroid-stimulating hormone and brain deiodinase in Atlantic salmon. Mol Cell Endocrinol (2020) 519:111056. doi: 10.1016/j.mce.2020.111056

207. Altner H, Zimmermann H. The Saccus Vasculosus. In: GH Bourne, editor. Structure and Physiology. New York and London: Academic Press (1972). p. 293-328. doi: 10.1016/b978-0-12-119285-3.50012-x

208. Wulliman FM, Rupp B, Reichert H. Neuroanatomy of the Zebrafish Brain: A Topological Atlas. Basel, Boston, Berlin: Birkhäuser Verlag (2012). doi: 10.1007/978-3-0348-8979-7

209. Maugars G, Dufour S, Cohen-Tannoudji JL, Quérat B. Multiple thyrotropin b-subunit and thyrotropin receptor-related genes arose during vertebrate evolution. Robinson-Rechavi M, ed. PLoS One (2014) 9(11):e111361. doi: 10.1371/journal.pone.0111361

210. Fleming MS, Maugars G, Lafont AG, Rancon J, Fontaine R, NourizadehLillabadi R. Functional divergence of thyrotropin beta-subunit paralogs gives new insights into salmon smoltification metamorphosis. Sci Rep (2019) 9 (1):4561. doi: 10.1038/s41598-019-40019-5

211. Gern WA, Owens DW, Ralph CL. Plasma melatonin in the trout: Day-night change demonstrated by radioimmunoassay. Gen Comp Endocrinol (1978) 34(4):453-8. doi: 10.1016/0016-6480(78)90286-1

212. Fontaine R, Ager-Wick E, Hodne K, Weltzien F-A. Plasticity of Lh cells caused by cell proliferation and recruitment of existing cells. J Endocrinol (2019) 240(2):361-77. doi: 10.1530/JOE-18-0412

213. Falcón J, Migaud H, Muñoz-Cueto JA, Carrillo M. Current knowledge on the melatonin system in teleost fish. Gen Comp Endocrinol (2010) 165(3):46982. doi: 10.1016/j.ygcen.2009.04.026

Conflict of Interest: The authors declare that the research was conducted in the absence of any commercial or financial relationships that could be construed as a potential conflict of interest.

Copyright (c) 2021 Ciani, Haug, Maugars, Weltzien, Falcón and Fontaine. This is an open-access article distributed under the terms of the Creative Commons Attribution License (CC BY). The use, distribution or reproduction in other forums is permitted, provided the original author(s) and the copyright owner(s) are credited and that the original publication in this journal is cited, in accordance with accepted academic practice. No use, distribution or reproduction is permitted which does not comply with these terms. 